\title{
YOU DON'T KNOW WHAT YoU'VE GOT 'TIL IT'S GONE: THE RULE OF LAW IN CANADA — PART I ${ }^{\wedge}$
}

\author{
JACK WATSON*
}

The expression "rule of law" is multifaceted and entails a complex network of concepts. Although the expression is used frequently, its intended meaning is often connected to the context in which it is invoked. As the rule of law is so often used in a contextual manner, its conceptual underpinnings are often only partially understood and appreciated. The author examines the historicity of the rule of law and analyzes the concepts contained within the expression in order to give an explanation of their meaning, importance, and implications. A theme persisting throughout the article is that of the threats to the rule of law, both in general and in our Canadian context. An importance of the article is that the author, having provided the reader with an account of the rule of law, also provides the reader with the ability to appreciate, discern, and be vigilant against the threats to the rule of law. This article is Part I of a two-part series.
L'expression «primauté du droit» comporte de multiples facettes ainsi qu'une panoplie de concepts complexes. Bien que l'expression soit souvent utilisée, sa signification voulue est généralement reliée au contexte dans lequel elle est invoquée. La primauté du droit étant fréquemment utilisée de manière contextuelle, ses bases conceptuelles ne sont souvent comprises et appréciées qu'en partie. L'auteur examine l'historicité de la primauté du droit et analyse les concepts contenus dans l'expression en question dans le but d'en expliquer le sens, l'importance et les implications. Les menaces à la primauté du droit, à la fois dans le contexte général et le contexte canadien, représentent le fil rouge de l'article. L'article est important en ce sens que l'auteur, ayant fourni au lecteur un aperçu de la primauté du droit, permet aussi au lecteur d'apprécier, de discerner, et d'être vigilant à l'égard des menaces contre la primauté du droit. Cet article est le premier d'une série de deux.

\section{TABLE OF CONTENTS}

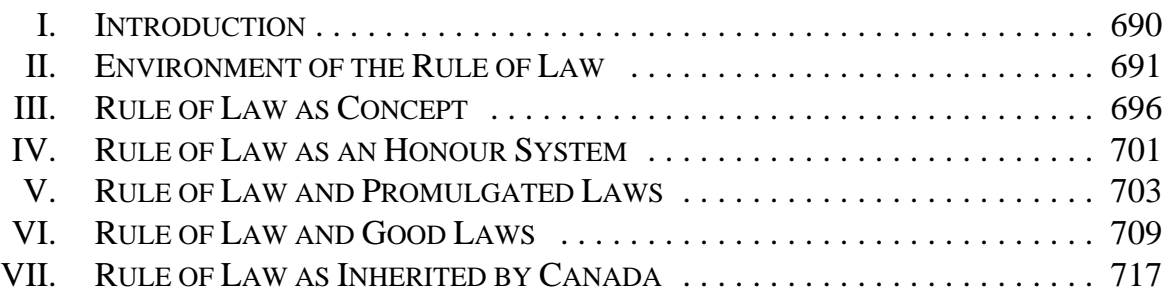

^ Joni Mitchell, (born Roberta Joan Anderson, 7 November 1943 in Fort MacLeod, Alberta), included this line in Big Yellow Taxi, which was originally written and performed by her in 1970 (Joni Mitchell, "Big Yellow Taxi” in Ladies of the Canyon, CD (Burbank, CA: Reprise, 1970); Wally Breese, "Biography: 1943-1963 Childhood Days" (January 1998), online: <www.jonimitchell.com/library/view.cfm?id= 2042>). The last part of the song seems intentionally ambiguous, as it is not clear who her "old man" was. Metro Toronto Police patrol cars were painted yellow until 1986 ("Getting Around,” online: $<$ www.torontopolice.on.ca/publications/files/misc/history /3t.html>).

The author attributes his passion for the rule of law to his patriotic and generous parents, both descended from hardy pioneers who came to Saskatchewan before it was a province. His parents and grandparents were in the front lines of courageous and diligent service to Canada in its travails of the nineteenth to twentieth centuries. By their efforts and that of their generation, he lived in a free and democratic nation and was able to graduate from Carleton University in 1969 (BA) and the University of Saskatchewan in 1972 (LLB). After 27 years as Crown counsel, he was appointed to the Court of Queen's Bench of Alberta in 2000, and the Court of Appeal of Alberta in 2006. 


\section{INTRODUCTION}

The "rule of law" is an expression that has become popular in political and legal discourse. There may not be any common understanding of even its essentials, let alone its details, and perhaps there never will be. The concept defies precise, let alone permanent, interpretation because it varies from society to society and from era to era. And it always has. Even before the concept had a name. ${ }^{1}$

Indeed, one of the definitive characteristics of the rule of law is the fact that it matures or declines along with the society that it shelters. It can become greater and more noble in its scope when it is further elaborated as a society grows itself more wise and more hospitable to great values - such as individual rights and freedoms. It can also diminish, and thin out to a mere patina of legality atop the governance of a state with little interest or commitment to individual rights and freedoms.

Canada has been blessed to have received a rule of law on its birth, and for the rule of law to have strengthened as Canada has evolved. But Canadians must remain alert to the threats to that inheritance, because those threats exist here just as they do everywhere else that humans live with one another in any degree of coherence. If we Canadians fail to fully appreciate the rule of law, to fully recognize its capacity for such positive development and to uphold it in our governance, we place it at hazard, and for no reason. There are subtle threats to the rule of law in Canada too.

This article attempts to describe the concept of the rule of law, which is an idea with a lot of luggage in a compact suitcase. ${ }^{2}$ It attempts to situate the concept in the framework of social thinking, particularly in free and democratic societies like ours. It proposes that a properly matured and respected rule of law is the best means to effectively secure "good" laws.

Next, it offers comment on how the rule of law came to be a practical reality for Canada, particularly in the history, tradition, and experience of the United Kingdom and then Canada as a legatee and beneficiary of that. The article then tries to describe how the language of our foundational law reflects that inheritance and the grand designs and purposes of the rule of law. And finally, it offers some observations about how the rule of law applies to governance in Canada, and to our tripartite form of government.

Publius Ovidius Naso, a Roman poet and scholar better known as Ovid wrote, "[s]o he gave them laws, lest the strong be all-powerful” (Aaron X Fellmeth \& Maurice Horwitz, Guide to Latin in International Law (Oxford: Oxford University Press, 2009) sub verbo “inde datae ledges ne fortior omnia posset”). Ovid had studied for the law, but later went into poetry evidently to the disappointment of his father. His poetry got him into trouble by $8 \mathrm{AD}$, when Ovid was banished to Tomis, on the Black Sea, by Emperor Augustus. This was without participation of the Senate or any Roman judge. Peter E Knox, "Ovid: (20 March 43 B.C. - A.D. 17)" in Ward W Briggs, ed, Dictionary of Literary Biography: Ancient Roman Writers, vol 211 (Detroit: Gale Group, 1999) 193: Ovid, Tristia, translated by LR Lind (Athens, Ga: University of Georgia Press, 1975) at 36.

2 In commencing, I wish to acknowledge, with great appreciation, suggestions by the Honourable Justice Russell Brown and by Richard Bruyer, LLM as to an earlier version of this article. 
We are talking about the greatest single achievement in human social order since the dawn of time. That is what the rule of law is. Maybe something better as to versions of how to foundationally organize human society will come. But to paraphrase Winston Churchill, it is better than all the other versions tried up to now. ${ }^{3}$

The depth, breadth, and universality of what the rule of law means to humankind cannot be captured easily. It does not deserve to be understated. This article is a feeble effort to depict the brilliance of it. Readers can say (with greater objectivity) if this article approaches that lofty goal.

\section{ENVIRONMENT OF THE RULE OF LAW}

The rule of law as a concept, as a belief, and as an integrating commitment of the mind (see the later discussion of the rule of law as concept), is surrounded by attitudes, which are potential threats.

First, there are those who believe that the rule of law has been mapped out quite adequately - thank you very much. They feel that we do not need any more built in legal protections because they only help the whiners or the dangerous. This view stunts the rule of law. It sets the stage for the disconnection with reality that will ultimately cause the rule of law to wither.

Second, there is the unimaginative failure to embrace the potential and value of the rule of law. This also places the whole concept at hazard. Nothing stays the same in a society. You never step into the same stream a second time. ${ }^{4}$ There is always a gulf between promulgated laws and society's circumstances on the one hand and the rule of law on the other. Yet the rule of law can promote and protect what is good and enduring.

Third, another threat to the rule of law lies in the casual way some people seem to associate the rule of law with inferior ideas, particularly selfish ones, either consciously or unconsciously. For example, judicial independence is an essential instrument in the maintenance of the rule of law, but recognizing that does not support the idea that emoluments or social status of individual judges deserve any sort of first rank in any debate about it. That type of association trivializes the rule of law. The rule of law is not a premise for benefits to its foot-soldiers any more than membership in a political movement. The rule of law has a transcendent and enduring quality long beyond such a tawdry rendering.

Fourth, and similar, is the danger of wrongful linkage when the rule of law is called in aid by government, particularly executive government, to justify suppression of disagreement

3 Sir Winston Leonard Spencer Churchill famously observed: “[m]any forms of Government have been tried, and will be tried in this world of sin and woe. No one pretends that democracy is perfect or all-wise. Indeed, it has been said that democracy is the worst form of Government except all those other forms that have been tried from time to time.” UK, HC, Parliamentary Debates, 5th Ser, vol 444 at 206207 (11 November 1947), online: Hansard 1803-2005 < hansard.millbanksystems.com/commons/1947/ nov/11/parliament-bill>.

4 This statement dates back to ancient Greece. See Plato, Cratylus, translated by CDC Reeve (Indianapolis: Hackett, 1998) at 402a. 
with actions or policies of government. Transitory dissonance of opinion is acceptable in a rule of law society. When the power of the state is turned against dissent, it teaches a bad lesson. There, the rule of law is, actually, separated from law and distorted to power.

The lesson is given not just to the persons on the receiving end of any such state power. Even the users are encouraged to link the rule of law with the mere application of state power. Those who dish it out feel justified in their actions. This reasoning and its flaws were eloquently expressed in the play, A Man for All Seasons, when Sir Thomas More, in answer to young Roper, who would have More go after an enemy who had as yet broken no law, said that he had no right (despite More's high office) to stop him from going on his way. ${ }^{5}$

More added to Roper, "[a]nd go he should, if he were the Devil himself, until he broke the law!” Roper was shocked by the suggestion of granting the Devil the benefit of law, but More was adamant:

What would you do? Cut a great road through the law to get after the Devil?

And when the last law was down, and the Devil turned round on you — where would you hide, Roper, the laws all being flat? ... This country's planted thick with laws from coast to coast — man's laws, not God's — and if you cut them down — and you're just the man to do it — d'you really think you could stand upright in the winds that would blow then? ... Yes, I give the Devil benefit of law, for my own safety's sake. ${ }^{7}$

This fourth threat to the rule of law, namely its invocation to justify the use of state power (even with majority support), is thus a linkage that not only obscures the real reasons to believe in the rule of law, but it also works to undermine those reasons. The rule of law may be related to "law and order" but not exclusively in the sense of J. Edgar Hoover. ${ }^{8}$

Fifth, there is a cacophony of voices about what the rule of law is, what it does, what it can do, and whether we need it or not. Each society has produced its own vision of law, just as it has produced its own languages. ${ }^{9}$ But where each society has and declares in an open and accurate manner its description of its version of the rule of law, the ability to discern the common ground between nations improves. Aleksandr Solzhenitsyn wrote:

Robert Bolt, A Man for All Seasons: A Play in Two Acts, (New York: Random House, 1960) at 65-67. Ibid at 66 .

Ibid.

J Edgar Hoover stated: “[j]ustice is incidental to law and order.” See Jeffrey Bernhardt, The Indian: America's Waking Dream, Berkeley Radicals, Wars, Riots, Dugs and Revolution (Bridgewater, NJ: Author Solutions, 2013) at 142

According to Genesis 11:4-9, communications between people suffered confusion as people scattered following the construction of the Tower of Babel. Evidently, this story of building a tower to (unsuccessfully) reach God with a consequent scattering of the people of the earth is replicated in a variety of both modern and historical cultures and religions. See e.g. Sir James George Frazer, Folk-Lore in the Old Testament: Studies in Comparative Religion Legend and Law, vol 1 (London: MacMillan, 1919) at 377-87. The allegory for law is that as such society seeks ideals in their context, the resulting social order differs. 
And through all those long ages when our world was so mysteriously, remotely separated, before it was crisscrossed by unifying lines of communication, before it was transformed into a united and tremulously beating clump, people were guided unerringly by their own life-experience in their own limited locality, in their own community, in their own society, and in the end in their own national territory. In those times it was possible for individual human eyes to perceive and accept a certain common scale of values: what was recognized as being average, as being improbable or unlikely, as being cruel, harsh; what was regarded as being beyond all bounds of evil-doing; what was honourable; what was deceit.

But then, in our most recent decades, humanity has imperceptibly and suddenly become united — hopefully united and dangerously united. So that a concussion or infection in one part is almost instantly transmitted to other parts, which sometimes have no immunity at all against it.... And in different regions different, particular, hard won scales of values are applied — and judgment is delivered uncompromisingly, boldly, solely on the basis of one's own particular scale of values and without regard for the scales of others. ${ }^{10}$

Solzhenitsyn proposed that the answer to this collision of opposing ideals, the reconciliation of them, as it were, could be found in free literature. This article ventures the suggestion that a common worldwide commitment to the rule of law would be the literature which would work the best.

The sixth and greatest danger to the rule of law, once established in a place like Canada, arises from the comfort level it bestows. When things are going generally okay, we start to pay less attention to governance topics. This can lead to a lack of awareness as to what the rule of law means, how it works, and worse, to apathy about the need to actively protect it. We do not need to be paranoid about government. But we do need to be sensitive to government actions that weaken the institutional braces and bonds of the rule of law in Canadian society.

The hydraulics of executive power, the lassitude of legislative participation, the misleading stability of inertia, the casualness of popular concession to government action that seems only to affect somebody else, and the tendency of people to assume things they are concerned about will not be disturbed to their disadvantage emerge in democracies. These are all social influences that tend to weaken society's hold on the rule of law. They are, ironically, products of the very confidence in our state institutions and in our fellow citizen that is generated by the rule of law.

The rule of law promotes confidence in our institutions and in our leaders because it is supposed to do so. Indeed, this is one of the principal objects as well as effect of the rule of law. Such confidence can maintain the rule of law and can keep society orderly, peaceful, generous, and fair in a benign circularity. And such confidence remains largely justified and justifiable. 
But such confidence can encourage a failure to recognize threats to the rule of law (often in seemingly harmless form) that arise through government actions that, on the face of things, seem to be good ideas at the time. It should also be recalled that the standards and instruments created under the rule of law exist to ensure that the holders of power (including judges) remain responsible agents of law and governance. These must be maintained precisely because the seats of power are not occupied by angels.

Arguably, there are two major themes of government in action which can be suggested as having been reflected in all forms and branches of government and in all governments of all time. These two themes can be encapsulated as "statements" to the public:

"We are the government. We are here to help. Trust us."11

"Nothing to see here. Move along.”

Most of our lives in Canada are spent not thinking about government. The subject may come up at the water cooler, or when an election is imminent, or when we are paying taxes. We tend to be happy to see the agents of government when a crisis arises. Government in Canada is benign and well intentioned. It is largely free of the defects seen in other less fortunate nations. We tend to take government at its word when it provides to us, as part of its explanation of any policy or process it engages in, some expression of one of the two "themes" mentioned above.

But neither sincerity of government motive nor the majority's bona fide perception of current social need are sufficient to guarantee that any policy, process, or decision is consistent with foundational values. The rule of law encompasses not just purposes but effects. While the rule of law in a given society is not always and inexorably the rule of "good" law, it is the systematic way in which "good" law can exist. So when we think of the rule of law, we should not confine it to the idea that high office holders of the executive are subject to the law in a manner such as, for instance, that a holder of high office is not immune from consequences of breach of law. ${ }^{12}$

The effect of the rule of law, and its influences and implications for society are much greater than that. As a result, the rule of law is inconvenient to government and, especially, to the executive branch which has the greatest scope of discretionary power. When some matter particularly (and rightly) concerns the public, such as crime or terrorism, it may not seem too damaging to the rule of law to temporarily set aside rules or principles given up by

11 To paraphrase President Ronald Reagan who, in a speech delivered on 12 August 1986, stated, “I’ve always felt the nine most terrifying words in the English language are: 'I'm from the Government and I'm here to help.'” Ronald Regan, “The Nine Most Terrifying Words,” online: YouTube < www.youtube. com/watch?v=xhYJS80MgYA>.

12 See e.g. Trudel Thibault c R, 2012 QCCA 2212, [2013] RJQ 1, leave to appeal to SCC denied, 35223 (23 May 2013). Here a former Lieutenant Governor of Quebec sought to claim the immunity recognized for the Crown in the expression, "The King Can Do no Wrong.” That concept did not apply to the person of the King: Lord Mackay of Clashfern, Halsbury's Laws of England, 4th ed reissue, vol 12(1) (London, Butterworths, 1998) at para 48. 
the rule of law because the present need is pressing and demanding, or the inroad against the rule of law seems minor.

Such "set asides" are not always minor even if they seem so. ${ }^{13}$ Let us not forget the examples of executives in otherwise democratic states seeking to overcome the judiciary, as with the efforts of Franklin Roosevelt to pack the United States Supreme Court in 1937, ${ }^{14}$ attempts by Indira Gandhi to control the Indian judiciary in the 1970 s, ${ }^{15}$ the hounding from the Bench of Chief Justice Anthony Gubbay in Zimbabwe, ${ }^{16}$ as well as events in Pakistan during the Presidency of Pervez Musharraf which have lately been the subject of charges by a later government against Musharraf himself. ${ }^{17}$

We can all point to examples of state executives moving to reorganize their nation's judiciaries in order to make them more amenable. ${ }^{18}$ Consider, for example, the incarceration of a Venezuela judge named Maria Lourdes Afiuni for the offence of having granted bail to a banker opposed to the regime of the late Hugo Chavez. ${ }^{19}$

It seems safe to assume that a fair number of the citizens, and perhaps even the majority of the citizens of all those countries (the United States, India, Pakistan, Venezuela), were sympathetically inclined to these steps being taken. An executive argument may well have been constructed for them that made sense at the time.

William Shakespeare in his three-part work on Henry VI confected a conversation involving a revolutionary named Jack Cade, who wanted to establish what he thought was a utopia (with himself as top dog of course), and Dick the butcher. The discussion followed a welcome to Cade by some locals:

All: God save your majesty!

As Hannah Arendt has observed, evil is at its root banal. Hannah Arendt, Eichmann in Jerusalem: A Report on the Banality of Evil (London: Faber and Faber, 1963).

14 See Noah Feldman, Scorpions: The Battles and Triumphs of FDR's Great Supreme Court Justices (New York: Twelve, 2010) at 103-121; Drew Pearson \& Robert S Allen, The Nine Old Men, (New York: Doubleday, Doran, 1936).

See Granville Austin, Working a Democratic Constitution: The Indian Experience (New Delhi: Oxford University Press, 1999), chs 7, 26.

16 David Blair, “Zimbabwe Chief Justice agrees to stand down” The Telegraph (3 March 2001), online: $<$ www.telegraph.co.uk/news/worldnews/europe/1324928/Zimbabwe-Chief-Justice-agrees-to-standdown.html>.

17 "Pervez Musharraf indicted in Akbar Bugti murder case” The Times of India (14 January 2015), online: $<$ timesofindia.indiatimes.com/world/pakistan/Pervez-Musharraf-indicted-in-Akbar-Bugti-murder-case/ articleshow/45883313.cms>.

18 To be sure, sometimes the suggestions are whimsical. Theodore Roosevelt is said to have sent a newspaper clipping to Supreme Court Justice Holmes which reported that the emperor of Korea had abolished his Supreme Court. Roosevelt appended a note: "Respectfully referred to Mr. Justice Holmes... The merit of the suggestion is obvious.” See Sheldon M Novick, Honorable Justice: The Life of Oliver Wendell Holmes (Boston: Little, Brown, 1989) at 262.

19 “Venezuela ends house arrest of Judge Maria Afiuni” BBC News (14 June 2013), online: <www.bbc. com/news/world-latin-america-22916391>. 
Cade: I thank you, good people — there shall be no money, all shall eat and drink on my score, and I will apparel them all in one livery that they may agree like brothers, and worship me their lord.

Butcher: The first thing we do, let’s kill all the lawyers.

Cade: $\quad$ Nay, that I mean to do. ${ }^{20}$

While humorists and other commentaries have sought to turn this dialogue to various purposes, serious and otherwise, Dick's suggestion stuck in our collective consciousness. It reflects the appeal of a calculated populist demagoguery that would sweep aside not just lawyers, but would sweep aside inconvenient law itself. ${ }^{21}$

Canada faces no such imminent and grim prospects. But all one has to do is think symbolically about an idea being attacked to appreciate the scope of that suggestion. William T. Gossett, a former president of the American Bar Association asserted in a speech in 1969: "the rule of law can be wiped out in one misguided, however well-intentioned generation. If that should happen, it could take a century of striving and ordeal to restore it, and then only at the cost of the lives of many good men and women."22

We in Canada received the rule of law as a gift from our ancestors. They struggled and even died to vouchsafe it to us. But although the rule of law is now a foundational characteristic of our nation, it is not invulnerable here. Canadians need to learn, understand, and remember what the rule of law gives us and what it means. That is the principal step in the defence of the rule of law and thereby the defence of the values that it represents and protects for all of us. We have the ability and need to defend the institutions and principles that sustain the rule of law for ourselves. We also have the duty to pass on to our descendants a rule of law that reflects and protects all of the positive values that our maturing civilization has come to realize.

\section{RULE OF LAW AS CONCEPT}

The concept of governance under law is ancient. Aristotle wrote, "the rule of law, it is argued, is preferable to that of any individual." ${ }^{23}$ Part of the allure of the concept of the rule

20 William Shakespeare, Henry VI, Part Two, Act 4, scene 2, lines 66-72.

21 Shakespeare in other contexts was not hesitant to criticize lawyers for their "quiddities," so the upshot of this was not to express sympathy for lawyers as such. See William Shakespeare, Hamlet, Act 5, Scene 1, 83-85.

22 William T Gossett, “The Rule of Law or the Defiance of Law?” (1969) 55:9 ABA J 823 at 824.

23 Aristotle, "Politics,” translated by B Jowett in Jonathan Barnes, ed, The Complete Works of Aristotle: The Revised Oxford Translation, vol 2 (Princeton: Princeton University Press, 1984) 1988 at 2042. In Book 1 he wrote:

Hence it is evident that the state is a creation of nature, and that man is by nature a political animal. And he who by nature and not by mere accident is without a state, is either a bad man or above humanity; he is like the "Tribeless, lawless, heartless one," whom Homer denouncesthe natural outcast is forthwith a lover of war; he may be compared to an isolated piece at draughts.

Ibid at 1987-88. Aristotle (384- 322 BCE), a student of Plato and teacher of Alexander the Great. Few philosophers or scientists can claim to the influence of Aristotle around the world on virtually every topic of human knowledge, notably as to understanding of human reasoning, rhetoric, and language. 
of law may lie in the very mystique about its meaning, which makes it capable of comforting adaptation to many philosophies. While it does not operate like a magical spell to ward off evil spirits, the essential character of the rule of law in operation almost resembles magic for the way in which it is omnipresent but usually undetected, and for the fact that its greatest influence lies in the movement of invisible hands.

Another part of the allure of the rule of law may be in the very onomatopoetic way in which the words flow, in that it sounds comforting and uplifting when it is spoken. Yet another intriguing characteristic is how its syntactical resonance appeals to the intellect. After all, it involves a marriage of the word "law," which has here the qualities of a noun (as a concept essential to the details of the formal and ongoing association of people) and "rule" which has here the qualities of a verb (as reflective of control of activity by people within that association). In those ways, then, it proclaims itself both as a defining noun for human society and as a verb for how society operates.

Another attraction of the rule of law lies in the fact that it does not, itself, purport to arrogate to itself its influence or power as a matter of conceit. In that respect, it is again distinguished from the hubris or pride of a human ruler. The expression connotes a stable neutrality and continuity that has no selfishness and involves a protective greatness intrinsic to our common understanding of civilization. It is only those prepared to abuse it who can turn law practice against the rule of law.

Against this, and to paraphrase the title of this article, you really don't know the rule of law until it is gone. Or at least you understand it much better when you think of what life would be like without a rule of law. Without the rule of law, there is really no law at all. With totalitarian rule of law, the "rule" that exists offers tenuous and erratic responses and is usually oppressive and even brutal.

Without any rule of law, there would soon be nothing left of real civilization. Civilization and the rule of law grew together. Were it otherwise, we would have no banks, no food stores, no tailors, no power plants, no television, no Internet. Nothing would be shared except perhaps in a meagre form of what may be an ancestor of the rule of law, namely what we think of as "family" and "tribe.” As Thomas Hobbes said about the state of nature:

[M]en live without other security than what their own strength and their own invention shall furnish them withal. In such condition there is no place for industry, because the fruit thereof is uncertain, and consequently no culture of the earth; no navigation, nor use of the commodities that may be imported by sea; no commodious building; no instruments of moving and removing such things as require much force; no knowledge of the face of the earth; no account of time; no arts; no letters; no society; and which is worst of all, continual fear, and danger of violent death; and the life of man, solitary, poor, nasty, brutish, and short. ${ }^{24}$

Even his errors had influence for centuries. He saw politics as an organism, and a city state as a political "community" not only to avoid injustice and favour economic stability, but also "for the sake of a good life” (ibid at 1987). See generally Alan Ryan, On Politics: A History of Political Thought From Herodotus to the Present (New York: WW Norton, 2012) at 71.

24 Thomas Hobbes, Leviathan, revised ed by AP Martinich \& Brian Battiste (Peterborough: Broadview, 2011) at 125-26. See likewise what Aristotle attributed to Homer, ibid. 
The rule of law can have meagre and arid forms. Those forms can persevere for a considerable time, but things will get worse. But whatever form it may take for a given collectivity of humans - regardless of how free or unfree, equal or unequal, democratic or undemocratic that collectivity may be - a form of rule of law, such as it may be there, is crucial to the survival of that society.

Even states governed by the worst of totalitarianism only function due to a form of rule of law. The rule of law there may be little more than a patina for, and continuously under challenge by, the intrusive and oppressive tactics of the governors. ${ }^{25}$ Any form of government will, however, ultimately collapse without a real and credible rule of law of some sort. For all the firepower a government may deploy in an attempt to keep a state together, it is inevitable without a thriving rule of law of some sort that, as William Yeats said:

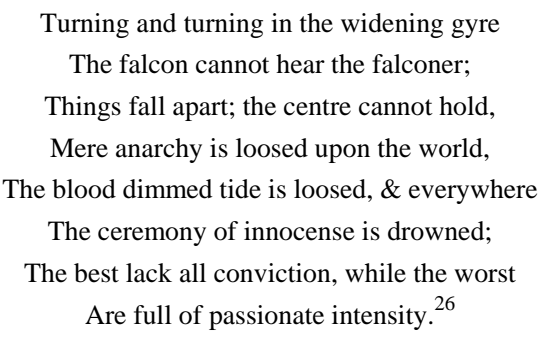

That said, erosion of the rule of law does not always and immediately lead to Hobbes' state of nature. That is so even though there continue to be examples of failed states in the twenty-first century. This article does not suggest that the only purpose of maintaining the rule of law is to prevent chaos. Indeed, when society begins to actually unravel, such institutions as the rule of law as might exist may well not be strong enough to deal with it. One builds and strengthens institutions of the rule of law to hopefully stay well back from that precipice.

Erosion of the rule of law seems more likely to follow in Western democratic societies from good intentions than from destructive ones. Eruptions of nihilism occur from time to time but we have addressed such perils. More hazardous is infectious self-delusions that can arise in the course of planning and governance generally. Planning by goal-oriented government and regulation of human activity and relationships are essential elements of promulgated laws. They are inevitable and are largely good and desirable things.

But our wise ancestors realized that all forms of state power must be regulated and responsible. Checks and balances of institutional strength that are pervasively recognized and supported are needed to avoid the capricious, promiscuous, or insensitive use of that power.

See e.g. Augustine, The City of God, translated by Henry Bettenson (London: Penguin, 2003) (“[r]emove justice, and what are kingdoms but gangs of criminals on a large scale?” at 139).

26 WB Yeats, "The Second Coming” in Thomas Parkinson \& Anne Brannen, eds, Michael Robartes and the Dancer: Manuscript Materials (Ithaca: Cornell University Press, 1994) 146 at 163. Yeats penned this work about the Apocalypse in 1919 (there is more to the poem) and it was published in different works thereafter. 
It does not matter which part of the scope of promulgated laws is involved, or which branch of government possesses the power.

For example, accusations of overreach by the judicial branch are not unknown - as discussed more below. Amongst what this article calls promulgated laws is legislated law, namely that which is produced through the legislative process. Where tripartite government, with an operative rule of law, exists, it will generally fall to the courts to resolve disputes over the meaning and scope of such legislated law. There is therefore controversy in terms of what the judiciary can do in that process.

In 2747-3174 Québec Inc. v. Quebec (Régie des permis d'alcool), ${ }^{27}$ Justice L'HeureuxDubé, writing for herself, discussed a dynamic and pragmatic approach to statutory construction. That approach was traceable back to Aristotle via William Eskridge. ${ }^{28}$ She offered this view: "Even if, according to the principle of parliamentary sovereignty, the judiciary does not legislate and merely applies the substantive law to specific cases, it retains a residual normative jurisdiction derived from the common law."29

But she expressed a sentiment of caution in 2747-3174 Québec. She observed that Eskridge had asserted that "Aristotle urged that application of general statutes to unanticipated cases requires the interpreter 'to correct the omission - to say what the legislator would have said had he been present, and would have put into law if he had known." 30 Responding to this she wrote:

In my view, Eskridge’s “pragmatic dynamism” provides the judiciary with a justification for manufacturing interpretations that are diametrically opposed to the clear purpose of a statute. Eskridge based this approach on an opinion expressed by Aristotle in his Nichomachean Ethics. Yet that opinion tends to diverge from the rule of law and état de droit concepts as they are accepted today in our democratic societies. To avoid basing the development of our judicial system on unsound theoretical foundations, we must therefore be extremely cautious about sociopolitical opinions expressed by the classical authors.

On the other hand, when it comes to pure methodology — such as Aristotelian-Thomist formal logic and the Socratic method — having recourse to the classical authors is obviously fully justified, inter alia in developing methods of legal interpretation. As correctly noted by Professor Nussbaum, the discipline of law could benefit from greater methodological rigor ("The Use and Abuse of Philosophy in Legal Education" (1993), 45 Stan. L. Rev. 1627, at pp. 1637-38):

Philosophy does not just conduct inquiries into specific topics; it also turns round and examines itself, asking what belief and knowledge are, what rationality is, what interpreting

[1996] 3 SCR 919 [2747-3174 Québec].

Aristotle’s Nichomachean Ethics was said to support "pragmatic” statutory construction. William N Eskridge, Jr, Dynamic Statutory Interpretation, (Cambridge, Mass: Harvard University Press, 1994) at 3, 50. 2747-3174 Québec, supra note 27 at para 151.

Ibid at para 173, quoting Eskridge, supra note 28 at 50. 
a text is, what methods are and are not conducive to understanding. Once again, this explicitness and rigor seems to me to have a great deal to offer to the law, which inevitably talks about evidence and knowledge, about interpretation and objectivity, and about the nature of rationality. The point is not that philosophers have some secret key to these difficult questions, but that they spend their whole lives working on them, whereas lawyers rarely spend much time on them at all. So there is at least some chance that philosophers' more systematic and detailed inquiries will offer something to the lawyer.

Law has become methodologically philosophical in some areas, in particular, in the debates about interpretation in constitutional law. But this self-scrutiny could be extended much further and could be pursued more rigorously, with benefit to all. [Emphasis added.] ${ }^{31}$

The effect of a judiciary that simply "calls it as it sees it," particularly because it considers itself smarter or more cultured than the hoi polloi is plainly to undermine the credibility and reliability of law generally, not to mention making the application of law unpredictable. In other words, judicial overreach is as contrary to the intent of the rule of law as is executive or legislative overreach. On the other hand, the judiciary is uniquely positioned to elucidate on the genius within the law, and to contribute to public understanding and appreciation of it.

In Western democracies, the rule of law is more likely to be undermined through gradual substitution of partiality for equality or process for fairness, rather than by dissolving social bonds or eliminating rights and freedoms rapidly or entirely. The first value to fall may be the truth. A modern day substitute for Dick the Butcher may well suggest that it is not the lawyers, but it is the Shakespeares that need to be disposed of first. Indeed, Charles Dickens advised wariness of ignorance more than want by what the ghost of the present Christmas told Scrooge about two children close to him: “"They are Man's,' said the Spirit. 'And they cling to me, appealing from their fathers. This boy is Ignorance. This girl is Want. Beware them both, and all of their degree, but most of all beware this boy, for on his brow I see that written which is Doom, unless the writing be erased."’32

A declining rule of law may commence with what is taught in schools, or what is permitted in the media, or in what is allowed as exercise of conscience or thought. These may well be one of the first things to suffer as power corrupts. There is precedent for that too. It is in the burning of books. Or it may commence with a gradual removal of respect for and protection of individual privacy. Or it may start with subtle restrictions on the ability of people to freely associate and disagree with others.

So what does this parade of horribles (that reflects both the absence of the rule of law and the weakening of the rule of law) tell us about the essential nature of the rule of law when it is in its best form? 


\section{RULE OF LAW AS AN HONOUR SySTEM}

First and foremost, the rule of law is an idea, a vision, a credo, and a cherished hope that, in its best essence, manifests itself as a pervasive honour system that sustains the associative characteristics of a mature society. The members of that society, both by their individual participation and by their communication of the faith to other members, continuously empower, engage with, and trust that honour system, and live their lives by it. Lon Fuller called it a "morality of aspiration." 33 Every time we judges talk about maintaining the "repute" of justice itself or of a justice system, we are not simply talking about the image or impression left by how a justice system seems to work, although, to be frank, that is part of it. We are also talking about a foundational duty that judges and courts have in preserving the rule of law by sustaining that honour system.

A justice system is not just an artistically-designed transit station advertisement that people pass by on the way to the real world. Nor is upholding the repute of the justice system simply a form of artisan work akin to maintaining the frontispieces of a Potemkin Village. The rule of law is not about the sterile hallways of a museum.

Nor is the rule of law about judges as such. Where the rule of law exists, it is possible to say that judges are not "fragile flowers." 34 The rule of law does not exist solely to ensure judges are taken care of alright. Judges occupy their offices temporarily. But the offices last, and it is the office which is victimized by such matters as contempt of court or executive interference. As said in Kopyto:

The concept of free and uninhibited speech permeates all truly democratic societies. Caustic and biting debate is, for example, often the hallmark of election campaigns, parliamentary debates and campaigns for the establishment of new public institutions or the reform of existing practices and institutions. The exchange of ideas on important issues is often framed in colourful and vitriolic language. So long as comments made on matters of public interest are neither obscene nor contrary to the laws of criminal libel, citizens of a democratic state should not have to worry unduly about the framing of their expression of ideas. The very life-blood of democracy is the free exchange of ideas and opinions. If these exchanges are stifled, democratic government itself is threatened.

History has repeatedly demonstrated that the first step taken by totalitarian regimes is to muzzle the media and then the individual in order to prevent the dissemination of views and opinions that may be contrary to those of the government. The vital importance of freedom of expression cannot be over- emphasized. It is important in this context to note that s. 2(b) of the Charter is framed in absolute terms, which distinguishes it, for example, from s. 8 of the Charter, which guarantees the qualified right to be secure from unreasonable search. The rights entrenched in s. 2(b) should therefore only be restricted in the clearest of circumstances.

The courts play an important role in any democratic society. They are the forum not only for the resolution of disputes between citizens but also for the resolution of disputes between the citizen and the state in all its manifestations. The more complex society becomes the greater is the resultant frustration imposed on citizens by that complexity and the more important becomes the function of the courts. As a result of their importance 
the courts are bound to be the subject of comment and criticism. Not all will be sweetly reasoned. An unsuccessful litigant may well make comments after the decision is rendered that are not felicitously worded. Some criticism may be well founded, some suggestions for change worth adopting. But the courts are not fragile flowers that will wither in the hot heat of controversy. Rules of evidence, methods of procedure and means of review and appeal exist that go far to establishing a fair and equitable rule of law. The courts have functioned well and effectively in difficult times. They are well-regarded in the community because they merit respect. They need not fear criticism nor need they seek to sustain unnecessary barriers to complaints about their operations or decisions. ${ }^{35}$

The rule of law is a state of mind, a gestalt, a kinship, even a faith of sorts. It is continuously evolving with society and its members learn and live together. And in a country as physically vast as Canada, it is an astonishing phenomenon of joining and relationship which transcends great distances and impediments.

The rule of law is constructed of individual commitments, undertakings, and, most importantly, beliefs, whether consciously held or not, which members of society enter into again and again. ${ }^{36}$ Because belief and confidence in the rule of law is what gives the rule of law its influence, it is also something which members of society, again whether consciously or not, teach their neighbours, children, and successors about. The elements of the rule of law are not frozen in time, but, like the matrix of belief and confidence that it reflects, the rule of law continues as the consensus of human wisdom, built upon human experience, and adapting to the evolution of human civilization.

The rule of law also reflects the power of the collective. But it is essentially an ideal of the mind that is quite separate from the imposed power of the state. It is a collection of norms, but each of those is adhered to by choice, reluctantly or not, and they tend to evolve over time. The rule of law does not exist because it is imposed on us. It is us. Vitally, it is all of us, individually and together. As John Stuart Mill said in the context of freedom of speech: "If all mankind minus one were of one opinion, and only one person were of the contrary opinion, mankind would be no more justified in silencing that one person, than he, if he had power, would be justified in silencing mankind." ${ }^{37}$ Mill added the following, after stating that “[a]ll silencing of discussion is an assumption of infallibility"38.

Ibid at 462-63 [emphasis in original].

In Jonathan Jackson et al, "Why Do People Comply with the Law? Legitimacy and the Influence of Legal Institutions” (2012) 52:6 Brit J Crim 1051 at 1054, the authors say:

The Metropolitan Police Force for London was established in 1829 by Robert Peel based on his much-quoted principles of accountability and policing by consent. While doubts exist as to the primary source of these principles, their spirit remains important. Phrases like 'The police are the public and the public are the police' and 'The ability of the police to perform their duties is dependent upon public approval of police actions' ... speak to a close social connection between the police and what were then 'subjects of the crown.' As mediators between citizens and the state — so the myth goes — the police were to work closely with the public, to regulate social order and to generate citizen consent. The police were uniformed members of the public. They enforced the law and abided by the law themselves. And they secured the consent of citizens to the law because of their close connection to citizens [footnotes omitted].

JS Mill, On Liberty and Considerations on Representative Government (Oxford, Basil Blackwell, 1946) at 14 .

Ibid at 15 . 
Yet it is as evident itself, as any amount of argument can make it, that ages are no more infallible than individuals; every age having held many opinions which subsequent ages have deemed not only false but absurd; and it is as certain that many opinions now general will be rejected by future ages, as it is that many, once general, are rejected by the present. ${ }^{39}$

We adhere to this ideal of the rule of law quite voluntarily, over and over again. For instance, we do so every time we choose not to exercise an opportunity to gain an unfair or mutually unacceptable advantage over others or over "the system." We adhere to this ideal also when, though we might rather not, we defer to what is called a "law" because it was promulgated according to operational rules of governance in the state.

In sum, we build and maintain the rule of law and its beneficent effects for all of us by continuously endorsing it as the way to live with one another. ${ }^{40}$ At the same time we endorse improvements in promulgated laws - which largely arise under the beneficial aura of the rule of law. When the continued engagement of citizens with one another is renewed with open education, shared tolerance, and encouraged charity, the rule of law builds further and strengthens the environment for further progress.

Because it is so compellingly persuasive and pervasive, the rule of law is not weak in modern free democracies, hence we may drift into thinking it can take care of itself. It is in a far more precarious place with its enfeebled content in totalitarian states or autocracies or the like. The legitimacy of consensus and cooperation in the rule of law is replaced in such unjust and arbitrary spheres essentially by might.

Might cannot hold forever. But in free democracies, the ideal of the rule of law can pass from mind to mind and from generation to generation, especially when manifested and institutionalized by checks and balances within society’s promulgated laws. Each person internalizes — not necessarily with a conscious and detailed understanding, but at least with a generalized appreciation of the notion - the rule of law as a secure legal environment where rights, freedoms, and obligations are capable of being known and relied upon. Each accepts a share of the responsibility of monitoring that legal environment.

\section{Rule of LAW AND Promulgated LAWs}

Once we get past trying to give the rule of law a single or frozen definition, and once we realize that the rule of law provides the essential but elaborate ingredient for continuity of human society by what we believe about it, we have made headway towards understanding why the imperfections of the governance of society inevitably relate to the manner in which that governance fails to respect the rule of law as best understood.

$39 \quad$ Ibid at 16.

$40 \quad$ Jackson et al, supra note 36 (adding in their survey of support for police actions in society that, “[w]e start, then, with the premise that obligation to obey is not uniquely constitutive of the legitimacy of legal authorities, but part of a broader set of ideas, beliefs and behaviours that individuals exhibit in relation to those authorities that combine to establish (or negate) their legitimacy” at 1054). 
The rule of law is connected to, but is not a grade or classification of, the promulgated laws of any state. Those promulgated laws range from the constitution of the state down to the smallest ruling of an administrative authority executing a policy created by regulation. In modern democratic societies, the following summary of the structure of promulgated laws may apply:

(a) Constitutional and other forms of foundational law has traditionally been, in a sense, category-to-category evaluation and prioritization of law, usually watched over by the judicial branch. In its reasoning about such law in cases, the judiciary largely thinks the matters through by comparing and evaluating categories provided by the constitution itself, or created by the legislated law or recognized as emerging as fundamental principles of judge-made common law. It tends to fall to the judiciary to organize those categories and their incidents to develop the specific hierarchy of categorization that will decide the specific situation.

In practical terms, the main job of the courts is generally to ascertain which of the facially applicable categories of law control the resolution of a particular debate involving law but being really about life. This type of debate arises in what some call "cases or controversies." ${ }^{41}$ Those determinations, in turn, work back to being interpretational markers for all present sources of law (constitutional, legislated, and judge-made common law) and all future new or revised laws. The determinations themselves become part of the judge-made common law.

(b) Legislated law has been situation-to-category definition of law, composed and enacted by the legislative branch. In doing so, the legislative body gathers in social information concerning situations. It creates categories of law based on this input. In doing so, the legislative body describes and defines the incidents for those categories which generally relate to their impact on people or institutions.

Legislated law tends to elaborate on, or more greatly detail, prior law although it also changes parts of it. It tends also to use the concepts of all sources of law. Indeed, the legislators are presumed to be aware of the history and language of law and to use legal terms or manners of expression in a way which conforms or explains that history and language. In so doing, legislated law is not merely refinement of the structural mechanics of processes of law but a very detailing of the social order itself. Legislated law may, therefore, change the judge-made common law as well as prior legislated law — and it regularly does.

But, significantly, the colouring and detailing of legislated law seems increasingly left to agencies of the executive, with the incorporation in legislative text of reference to standards and powers of regulation. ${ }^{42}$ 
(c) Executive or administrative law has been situation-to-situation application of law, carried out by the executive branch or its agencies. The executive in all its various agents and emanations, acts (or perhaps more accurately reacts) to the circumstances of situations. Each such action is under law and constitutes therefore an application of law.

In so doing, the executive is expected to remain within the confines and jurisdiction of each category and incident definition as may be provided by the legislated law. The executive must also remain within the limits or rules of the Constitution. The executive branch and its agents must be cognizant of the interpretational assistance of the judge-made common law concerning those categories, failing which the legality of the action is in question.

Such executive action is also a form of law-making, since each action may well be considered precedential or influential on later similar situations. The actions of individual state agents, such as police officers, may guide each other, but that is neither legislated law nor common law, since it is not innate to executive action by individuals, even ministers of the Crown, to create categories by doing so.

In recent years, however, executive agencies and even individuals have taken to establishing categories of their own without returning to the legislatures for approval. This is done by way of regulation and rule making. ${ }^{43}$ This phenomenon, which may be a potential threat to the tripartite balance of democratic governance, appears to be a part of a trend towards centralization of power within the executive branch because it largely has the endorsement of legislation. ${ }^{44}$ The need to accommodate this phenomenon within the rule of law has expanded the justification for, as well as scope of, the process we call judicial review. ${ }^{45}$

be vested." See also Thomas v Mowbray, [2007] HCA 33, [2007] 233 CLR 307. But, as noted below in the discussion of elements of the rule of law, the rule of law in a tripartite free democracy cannot permit imposition by the legislative and executive branches upon the courts of direct obligations to execute the policy of such branches in a manner which impairs the institutional integrity or judicial character of the courts.

Intriguingly, the modern regulatory landscape, planted thick with laws, appears to be modernizing by additional steps that are more of a carrot than a stick approach. This type of action generalizes the focus to promote behavioural changes and attitudinal adjustment rather than dictating conduct through specific rules.

44 It is not necessarily a threat to the tripartite form of government if the rule-making authority is given or implicit in the authorizing legislated law, if the rules thus made are within the jurisdiction and for the purposes of that legislated law, and if the rules are applied according to their terms and for those purposes under the watchful eye of judicial review. But let's be frank: it is arguably a form of transfer of legislative authority to the executive branch even if it dates back more than a century.

45 Courts accept the duty to review such executive-made law: see e.g. Parada $v$ Workers' Compensation Board Appeals Commission (Alta), 2011 ABCA 44, 499 AR 169 at paras 25-28 cited in Martin v Workers' Compensation Board (Alta), 2012 ABCA 248, 536 AR 121 at para 5, aff'd 2014 SCC 25, [2014] 1 SCR 546. See also Katz Group Canada Inc v Ontario (Health and Long-Term Care), 2013 SCC 64, [2013] 3 SCR 810 at paras 24-28. See also Chevron USA Inc v Natural Resources Defense Council Inc, 467 US 837 (1984); Robertson v Methow Valley Citizens Council, 490 US 332, (1989); Christopher v Smithkline Beecham Corp, 132 S Ct 2156 (2012). 
Constitutional, legislated, and judge-made law along with the regulatory and administrative law generated by executive agencies are all part of what this article means by the promulgated laws of society. The rule of law embraces and transcends all these things. It is an omnipresent influence that is made up of the consensus, articulation, adoption, belief, and confidence that created the environment for those promulgated laws. The rule of law upholds and validates the legal means by which all those forms of promulgated law come into existence. It does the same for how they are amended, removed, or replaced. Importantly, it does the same for how they are administered and applied in the practical governance of society and its members. The rule of law maintains a weather eye on what is done with all those forms of promulgated law.

Less visibly, perhaps, the rule of law provides references, standards, and principles, that lie in the voids between any one rule and another rule that forms part of any promulgated law. ${ }^{46}$ All promulgated laws produced by any aspect of government have spaces within and between them. In that penumbral space, the modern rule of law is hospitable to a non-finite set of desirables and aspirations.

Promulgated laws do not have accidental gaps or zones of discretion in them. The source of such laws usually in generating the specific law, intend there to be such room to manoeuvre. A proper rule of law can provide the normative space and the fences designating the zone of flexibility. The rule of law can, in addition, provide a set of guiding principles which illuminates the margin of appreciation of what is relevant and what are the questions to be answered. In other words, the rule of law is not just a collection of rules. The rule of law can be the very fabric of legal consciousness altogether. The values it identifies, verifies, and promotes permeate the space between promulgated laws, in a sense acting as a form of juristic dark matter.

One longstanding debate about the rule of law has concerned whether it should be treated as being restricted to democratic governance in free societies. Certainly the rule of law (as free people desire it to exist) should sustain democracy. The rule of law is more vital and telling in a free and democratic society. But, as noted, the rule of law is not necessarily limited to a phenomenon that people in democratic countries can feel good about. A discussion of the relationship between the rule of law and "good" laws appears later in this article.

For present purposes it is sufficient to note that a form of the rule of law exists in all organized societies. It only disappears completely in what we call the "failed state" as depicted in Hobbes. No state has a form of the rule of law which is identical to every other state. But the further away one gets from a free, equal, and democratic society, enfeeblement of the rule of law follows, and the slope shifts further down. In states governed by violent and tyrannical bullies, the rule of law is in a poor condition. Most of its benign characteristics

46 One says "less visibly" because the rule of law, and such subrules as "full faith and credit" as between legal authority jurisdictions in Canada are often unwritten. Babcock v Canada (Attorney General), 2002 SCC 57, [2002] 3 SCR 3 (the "unwritten constitutional principles," including the rule of law, "are capable of limiting government actions” at para 54). See also Reference re Secession of Quebec, [1998] 2 SCR 217 at para 54. 
or institutional protections and benefits are, in such states, either undeveloped or absent. A leader and his or her tribe will govern, usually brooking no dispute as to their power and inordinately suspicious of any debate about any promulgated laws for fear of what may come of any such debate. Nonetheless, traces of the rule of law remain even in totalitarian states. Criminal gangs and violent prison inmates have their own versions of the rule of law as well.

These phenomena may be little more than a preference for good manners, although they largely seek to enforce reliability. The natural inclination of intelligent or civilized people towards sensible and peaceful interaction — which inclination holds out hope that things will get better - is hard to squelch even inside tyrannies. Even in the worst of societies there will be customs of ordinariness. People obey some rules in the way they dress for the weather. Common languages will continue even if they evolve. People will have some sensitivity to, and regard for, the views of others, howsoever localized the awareness.

As said, the rule of law can be much more. And it is likely the product of learning and intelligence as much as anything else, which is a reason it may be capable of revival and improvement even at the cusp of loss. The phenomenon of rule of law existing without the usual structural attributes of government is exemplified in the ancient forms of what has been called the lex mercatoria, namely the collection of customs concerning trade and commerce dating to times without much other law in place. ${ }^{47}$

This economic application of the rule of law was recognized more recently in the writings of F.A. Hayek who explained that, amongst other things, the rule of law benefits the free market due to the confidence it provides for investments and future plans when he stated: "[U]nder the Rule of Law the government is prevented from stultifying individual efforts by ad hoc action. Within the known rules of the game the individual is free to pursue his personal ends and desires, certain that the powers of government will not be used deliberately to frustrate his efforts." 48

In the same work, Hayek went on to focus the rule of law on its distinction from of arbitrary government:

The distinction we have drawn before between the creation of a permanent framework of laws within which the productive activity is guided by individual decisions and the direction of economic activity by a central authority is thus really a particular case of the more general distinction between the Rule of Law and arbitrary government. Under the first the government confines itself to fixing rules determining the conditions under

See JH Baker, “The Law Merchant and the Common Law Before 1700” (1979) 38:3 Cambridge LJ 295 at 299.

FA Hayek, The Road to Serfdom: Text and Documents, definitive ed by Bruce Caldwell (London: University of Chicago Press, 2007) at 112-13. He argued at 67 that Western democracies had "progressively abandoned that freedom in economic affairs without which personal and political freedom has never existed in the past” and that society mistakenly tried to ensure continuing prosperity by centralized planning, which inevitably leads to totalitarianism. Friedrich August (von) Hayek was a winner of Nobel Prize for Economics. The title of his most famous work, The Road to Serfdom, was drawn from Alexis de Tocqueville's writings on the "road to servitude.” It is said that Margaret Thatcher treated the latter book as a governing influence on her view of the role of government. So said Winston Churchill before her. See Alan Ebenstein, Friedrich Hayek: A Biography (New York: Palgrave, 2001) at 116, 209. 
which the available resources may be used, leaving to the individuals the decision for what ends they are to be used. Under the second the government directs the use of the means of production to particular ends. The first type of rules can be made in advance, in the shape of formal rules which do not aim at the wants and needs of particular people. They are intended to be merely instrumental in the pursuit of people's various individual ends. And they are, or ought to be, intended for such long periods that it is impossible to know whether they will assist particular people more than others. They could almost be described as a kind of instrument of production, helping people to predict the behavior of those with whom they must collaborate, rather than as efforts toward the satisfaction of particular needs. ${ }^{49}$

Similarly, the Twelve Tables of Rome had a form of use for centuries even when Rome was no more, producing brocards. ${ }^{50}$ As William Blackstone said, Rome (and Hammurabi millennia before that) gave us the notion of the "proctor" who could represent individuals before the courts two thousand years ago. ${ }^{51}$ This is another example of the fact that the rule of law is a remarkable human idea.

In totalitarian states, the fact that a rule of law of sorts staggers on may perhaps also be reflected in the spirit animating this Belloc couplet:

And always keep a-hold of Nurse

For fear of finding something worse. ${ }^{52}$

In other words, dura lex sed lex..$^{53}$ An alternative way of looking at how the rule of law functions in despotic states may be reflected in something Samuel Coleridge has written. He was speaking not of the chilled deference and forward motion within the realm of oppressive governance but more broadly of life in fear of the alternatives whether or not they are seen coming:

Hayek, ibid at 113 [emphasis in original].

Michael Steinberg, "The Twelve Tables and Their Origins: An Eighteenth-Century Debate” (1982) 43:3 J History Ideas 379. The term "brocard" refers to the familiar Latinisms that continue to march on through the modern era (Black's Law Dictionary, 8th ed, sub verbo "brochure"). These include: pacta sunt servanda (contracts are the law for parties and courts should enforce them): Braut v Stec, 2005 BCCA 521, 51 BCLR (4th) 15 at para 15 . The very existence of "brocards" or legal maxims reflects how the rule of law survives in the common mind. One such brocard encapsulates the criminal law: actus non facit reum nisi mens sit rea (all crimes are constituted by the combination of prohibited conduct or neglect and mental fault): Re BC Motor Vehicle Act, [1985] 2 SCR 486 at 513. Others are durable for their constitutional character, such as nullum crimen, nulla poena sine praevia lege poenali (penal laws must exist before the fact or there is no crime): $R v$ Meikle, 2003 BCPC 162, [2003] 4 CTC 294 at 37.

51 Sir William Blackstone, Commentaries on the Laws of England, vol 2 (New York: WE Dean, 1838) at 23 refers to the rising of the legal profession: "cum olim in usu fuisset, alterius nomine agi non posse; sed, quia hoc non miniman incommoditatem habebat, coeperunt homines per procuratores litigare" ("Although formerly it had been the custom for no one to act in the name of another; yet, as this was attended with great inconvenience, men began to carry on law-suits by proctors": JW Jones, A Translation of all the Greek, Latin, Italian, and French Quotations which occur in Blackstone's Commentaries on the Laws of England (London: Charles Reader et al, 1823) at 146-47). This could only happen if people believed that there was an effective legal system in place beyond imperial announcements.

$52 \quad$ H Belloc, Cautionary Tales for Children (London: Duckworth) at 16.

53 "The law is harsh, but it is the law." This old brocard was cited in La Souveraine, Compagnie d'assurance générale v. Autorité des marchés financiers, 2013 SCC 63, [2013] 3 SCR 756 at para 93. 


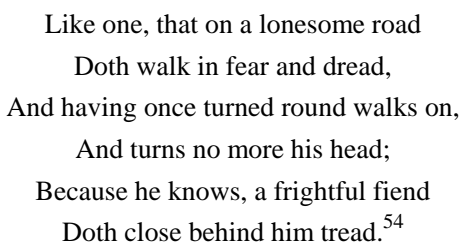

But in free democracies, where equal justice under law is closer to reality, the rule of law is manifested in a greater variety of ways, and it is increasingly inclusive and benign. This increase is directly related to learning, knowledge, experience, reasoning, and their ultimate product, wisdom. Rule of law becomes stronger and more pervasive and yet more a matter of voluntary adherence to standards and less invasive of individual life. So does this mean the rule of law is inevitably associated with "good” laws?

\section{RULE OF LAW AND GOOD LAWS}

The strength and merit of the rule of law is enhanced or developed as civilization and wisdom increase. Beyond elaborating the core principles within the rule of law, each element of improvement of the law adds to and invigorates the entire concept of the rule of law. That is because the existence and strength of each improvement enhances the motive for confidence and belief in the law.

As a consequence, the answer to the question whether the rule of law means (or should mean) only the rule of "good" law is that a thriving rule of law is the environment which allows the emergence of a common consensus of what is "good" law. In turn, the existence of good laws amongst the promulgated laws adds authority and influence to the rule of law generally. Then back again, the aura and penumbra of the rule of law creates space for the natural elaboration of good laws.

Put another way, the more the architecture of promulgated laws includes practically effective laws that serve equal justice, fair hearing, limits of power, legitimacy of exercise of discretion, and so on, the more powerful the basis the rule of law becomes and the more good it does. So it is not as if the rule of law does not exist unless it is the rule of "good" law. As noted above, a form or appearance of the rule of law may stagger forward with oppressive simplicity - for a time. But such governance carries within it the phlegm of anarchy or tyranny, and the seeds of its own demise.

Some have contended that the rule of law must, for its very validity, include such aspects of law as bills of (human) rights. ${ }^{55}$ Tom Bingham has asserted that the rule of law, "demands

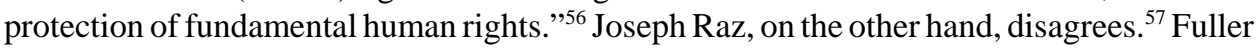


proposed eight features of the rule of law in his seminal work the Morality of Law, and was promptly mocked by H.L.A. Hart for assigning the notion of "morality" to this framework of symptoms of societal illness. ${ }^{58}$ Hart's view was supported to some extent by Matthew Kramer, but Kramer did not despair of the possibility of integration of morality with law. ${ }^{59}$ Hart contended for a more positivist approach to law in which he distinguished social habits (which this article suggests can contribute to the rule of law) from rules. ${ }^{60}$

Patrick Devlin endorsed the view that popular morality should be allowed to influence lawmaking. ${ }^{61}$ So far so good. But significantly, Devlin actually missed the boat as to the essence of the rule of law as much as Hart did. The nature of ongoing moral endorsement of the rule of law should not be a matter of majoritarian preference from time to time. That outlook can threaten the rule of law as previously noted in this article. ${ }^{62}$ Rather, the rule of law should connote more enduring and foundational aspects of freedom, rights, and equality.

For his part - and whether or not he exaggerated his use of "morality" to introduce his core notions of the rule of law - Fuller suggested the following symptoms show a state on its way to failure of the rule of law: (1) the lack of rules or law, which leads to ad hoc and inconsistent adjudication; (2) failure to publicize or make known the rules of law; (3) retroactive legislation; (4) unclear or obscure legislation that is impossible to understand; (5) contradictions in the law; (6) demands that are beyond the power of the subjects and the ruled; (7) unstable legislation (such as daily revisions of laws); and (8) divergence between adjudication or administration and legislation. ${ }^{63}$

But we do not need to dwell on the debate as to whether it is appropriate to call fundamentals of the rule of law morality. That debate seems as much semantical as anything

Fuller's eight principles for legal rules were that they should be: (1) expressed in general terms; (2) publicly promulgated; (3) ordinarily prospective in effect; (4) understandable; (5) internally consistent; (6) must not require the impossible; (7) must be stable enough to be reliable; and (8) the rules must be administered in a manner consistent with their wording (Fuller, supra note 33 at 39). On this, Fuller and Hart played intellectual badminton in Volume 78 of the Harvard Law Review (HLA Hart, Book Review of The Morality of Law by Lon L Fuller, (1965) 78:8 Harv L Rev 1281). In his Book Review of The Morality of Law, Hart characterized Fuller's insistence on classifying principles of legality as a "morality" as a source of confusion and misleading (ibid at 1285). He asserted that Fuller's approach led to "grotesque results" (ibid at 1286) and "fallacy" (ibid at 1287) and "ancient libel on positivist thinkers" (ibid at 1289) and embodied "his own high intolerance" of other ideas (ibid at 1290). More directly, Hart sheared the essence of Fuller's challenge to his own views with vigour (ibid at 1288). Matthew Kramer, Where Law and Morality Meet (Oxford: Oxford University Press, 2004). Kramer states at 2 that inclusive legal positivism holds that "some degree of moral worthiness is a necessary condition" for a law and it "allows that moral precepts can figure among the criteria that guide officials" ascertainment of the law." HLA Hart, The Concept of Law (London: Oxford University Press, 1961) at 54-59. Patrick Devlin, The Enforcement of Morals (London: Oxford University Press, 1965).

Indeed, Devlin initially used the idea to favour laws against homosexuality in 1959 after the Wolfenden Report. Devlin eventually changed his mind by 1965 and he argued that the law had no business interfering with private acts that harmed nobody. Devlin would certainly denounce the fact that homosexuality faces not merely discrimination but murder, even now in allegedly civilized countries with versions of the rule of law. Ronald Dworkin, "Lord Devlin and the Enforcement of Morals" (1966) 75:6 Yale LJ 986.

$63 \quad$ Fuller, supra note 32 at 39. 
else. ${ }^{64}$ Bearing in mind that law only works if people obey it, and if they obey it voluntarily and without threat, then it presumably accords with some internalized sense of morality of such persons.For present purposes, the practical question is not whether the rule of law, as a matter of analytical demand, necessarily includes and reflects moral ideas, such as equality, human rights and freedoms, or not. The rule of law touches all law in its logical sense. Laws of human rights and freedoms are obviously not excluded from the scope of the rule of law. But to adapt from what Solzhenitsyn said, ${ }^{65}$ even free and democratic societies will differ as to the degree that promulgated laws reflect social concerns, charity, or equality and thus are part of the mortar of the rule of law.

The crucial point is that what builds up the rule of law, what makes it stronger and what makes it more valid and aspirational, is the existence within any set of promulgated laws of (1) protections for human rights and freedoms, together with (2) durable institutions and systems for fair process and for real justice in the administration of the promulgated laws, and (3) the existence of an effective method of governance of government itself including some method to "watch the watchers." 66

Seen another way, a rule of law society should be what a person (under an adapted version of the model of John Rawls) would presumably choose for the society for her to live in, if she were given the choice. ${ }^{67}$ It would not just be one which asserts the values and aims of free democracy, the integrity and the safety of governance by consensus. Such a society would not just be one where the aspirations that we share for real equality, understanding, respect, and appreciation for one another can be met. It would not just be one with opportunity for constructive and happy lives. It would be a society where the rule of law protected all those things.

Rawls raised an intriguing question which may assist our understanding of the rule of law. He posed the question of what one would do if, before being born, one was given a choice about the society one would want to live in. The framework of the choice he suggested was that one would not be told ahead of time what one's social and economic status in life is going to be, or how genetics will apply, or what one's talents and abilities will be. In other words, behind a veil of ignorance.

The unknown choice might be between affluence or destitution. One might be very handsome or very plain. One might have unusual abilities or be very average or even be limited or disabled. The choice could be a society that is egalitarian, just, without much discrepancy between people, and in which one would be expected to be "his brother's

Kramer suggests that Fuller's thoughts were primarily reflective of efficiency requirements as much as they might seem to reflect morality. See Matthew H Kramer, “The Big Bad Wolf: Legal Positivism and Its Detractors” (2009) 49 Am J Juris 1 at 1-2.

65 Supra note 10.

66 Quis custodiet ipsos custodes? is a Latin phrase traditionally attributed to the Roman poet Juvenal from "Satire VI" in his Satires (Christopher Kelk, The Satires of Juvenal: A Verse Translation (Lewiston, NY, 2010) at 126). The phrase is literally translated as: "who is to keep guard over the guards themselves?” (Juvenal, The Sixteen Satires, translated by Peter Green (London: Penguin Books, 1974 at 140). In actuality, the expression arose in the context of guards for marital fidelity in a sometimes comic context. But the expression has gathered much greater significance since. John Rawls, A Theory Of Justice (Cambridge, Mass: Harvard University Press, 1971) 
keeper." Or one could live in a more stratified society — a society with more inequality but the prospect of positive distinctions.

Rawls anticipated that most sensible people would elect for a society with egalitarian characteristics so that they would not risk ending up in a weak, vulnerable, or deprived condition. So he suggested that even aware of the alternatives we should pick the better one. But, with all due respect to Rawls, the society most likely to be the best answer to his question would be a society governed by the modern ideal of the rule of law. That is because human characteristics are not as altruistic, consistent, or level as Rawls' idealistic choice might be thought to anticipate.

For example, any form of distributive action is impossible without the rule of law. On its own the idea of sustained consensus is no more realistic than the withering away of the state. People are different. The natural and inevitable impetus to deploy those differences, advantageously or wisely or otherwise, cannot be ignored.

The rule of law in its uplifted understanding is, therefore, not merely the antithesis of Hobbes' dystopia of continuously precarious, cold, and hungry solitude. Hobbes had a rather absolutist answer to that condition. Nor is it a distorted formulation deployed by tyrants to clothe their dictates in the garb of law. More optimistic about the rule of law in free societies, and certainly more influential in modern Western democracies was the view of John Locke, who said that movement from the state of nature was possible:

\footnotetext{
If man in the state of nature be so free, as has been said; if he be absolute lord of his own person and possessions, equal to the greatest, and subject to no body, why will he part with his freedom? why will he give up this empire, and subject himself to the dominion and controul of any other power? To which it is obvious to answer, that though in the state of nature he hath such a right, yet the enjoyment of it is very uncertain, and constantly exposed to the invasion of others: for all being kings as much as he, every man his equal, and the greater part no strict observers of equity and justice, the enjoyment of the property he has in this state is very unsafe, very unsecure. This makes him willing to quit a condition, which, however free, is full of fears and continual dangers: and it is not without reason, that he seeks out, and is willing to join in society with others, who are already united, or have a mind to unite, for the mutual preservation of their lives, liberties and estates, which I call by the general name, property. ${ }^{68}$
}

As noted further below, Locke's vision was more conducive to the rule of law as herein discussed because he perceived that a social contract involving the governed and the governors was possible. His vision included a structural conventionality which was at least conceptually consistent with the emergence of the rule of law.

The views of Locke and John Selden were major antecedents to the development not only of tripartite democratic government but to the rule of law, albeit, as history teaches, both things evolved simultaneously and neither Locke nor Selden specifically contended for any 
judicial power to survey the actions of Parliament. ${ }^{69}$ Quite the contrary, actually, since they believed in the sovereignty of Parliament.

Nonetheless, an example of their complementary contribution to the rule of law arises in their response to the assertion by Marcus Cicero that "salus populi suprema lex esto" (the safety of the people shall be their highest law). ${ }^{70}$ Locke interpreted this aphorism as the wellbeing of the people being supreme, and accordingly he used it as the epigraph in his Second Treatise on Government treating it as a fundamental rule for government. ${ }^{71}$

Selden, on the other hand, having been chucked into prison more than once (for instance at the pleasure of the Duke of Buckingham whom he challenged and for his involvement with the Petition of Right, 1628) ventured the opinion following an extended career up and down the political stages that, "[t]here is not anything in the world so much abused as this [Cicero's] sentence." ${ }^{72}$ Bingham asserts this comment of Selden as a proposition to remember about the rule of law when in times of terrorism. ${ }^{73}$

The rule of law embodies both the rationale and the means for the control of state powers, the preservation of human rights, freedoms, and security, the upholding of equality of opportunity and treatment, and the existence of a reliable and predictable set of co-existence rules and values that allow us to securely hold, conserve, and contribute what we have achieved individually and together. How so?

Translated to real-world living, belief in the rule of law encourages a shared confidence in law generally, a common acceptance of the foundational legitimacy of promulgated laws and a willingness to accede to the integrity not only of legal institutions but of all aspects of governance. As noted above, though, such belief, acceptance, and willingness should be escorted by an ongoing attention to the health of the rule of law and the values it sustains.

John Selden was a Member of Parliament who in 1628 was involved in drawing up and carrying the Petition of Right. He was also an historian who wrote England's Epinomis and Jani Anglorum; facies altera, works which dealt with the progress of English law down to Henry II; and The duello, or Single Combat, in which he traced the history of trial by battle in England from the Norman Conquest. After that he continued to contribute to modern understanding of the scope and function of history. Paul Christianson, "Selden, John (1584-1654)" in HCG Mathew \& Brian Harrison, eds, Oxford Dictionary of National Biography, online ed (Oxford: Oxford University Press, 2008). Marcus Tullius Cicero, "De Legibus" Cicero in Twenty-Eight Volumes, vol 16, translated by Clinton Walker Keyes (Cambridge, Mass: Harvard University Press, 1970) at 466-67.

Locke, supra note 68 at 2.

Samuel Harvey Reynolds, ed, The Table Talk of John Selden (Oxford: Clarendon Press, 1892) at 131. A compelling read is the story of Selden in George W Johnson, Memoirs of John Selden: And Notices of the Political Contest During His Time (London: Orr \& Smith, 1835). According to this work, amongst those Selden stood against was the Duke of Buckingham, a figure lost to the memory of most but scholars, but seemingly an éminence grise behind James II and Charles I and a figure as venal as Sejanus of the time of Tiberius (ibid at 122). Yet Selden seems to have been of such a moderate and law-devoted perspective that neither Charles I nor Cromwell moved lethally against him. would give up essential Liberty, to purchase a little temporary Safety, deserve neither Liberty nor Safety.” This was first written by Franklin for the Pennsylvania Assembly in its "Reply to the Governor" (11 November 1755), online: Franklin Papers < franklinpapers.org/franklin/framedVolumes.jsp?vol=6 \&page $=238 \mathrm{a}>$. 
Bills of rights and freedoms tend to be set out in broad and open-ended terms that appeal to the mind and sentiment of everyone. ${ }^{74}$ A key reason for this is that such broader formulations were feasible to begin with. Apart from trivializing the discussion, it is unlikely that the rest of a society would spend time talking about, let alone guaranteeing, the right of a member to own a dozen cows and sell the milk. That the language of rights and freedoms is wide signifies both its importance and the practical need to avoid advance disagreements about points that may arise at the ground level. ${ }^{75}$ Particularly, claims of rights and freedoms have a potentially disintegrative effect on society because they are taken from the comforting level of abstraction down to the practical where some feel their ox is being gored when they tangle with the difference between racial neutrality and affirmative action. ${ }^{76}$

What the desirable form of the rule of law brings to these typically passion-raising events is the law's technique for setting the process for peaceful and informed debate, and for framing the specific questions against comprehensible standards. In other words, while the rule of law does not necessarily provide guidance as to answers to the disputes, it will provide a format of reasoning that those affected have found at least generally satisfactory in the resolution of their other disputes.

As society matures, and as the values imbedded in the rule of law are increasingly elaborated, the rule of law as a source of standards, principles, and guidance may assist directly in the development of the answers. But even short of that, the desirable form of the rule of law provides for the means of getting there. The rule of law in its nature, when taken up, embodies what the people interested in a particular debate will have previously accepted as an open and fair way to get to an outcome.

The rule of law involves an ongoing accumulation of notions, interpretations, and judicial choices which are helpful in guiding legal reasoning, notably as to hard choices, even if those choices were not previously forecast. The rule of law needs an ongoing personal investment in, and adherence to, the specifics of law on a routine basis from the members of society. So said, the rule of law is an honour system. Those who do not believe much in the law at all might characterize it as a Ponzi scheme. But we do not build societies on such naysayers and such deconstructionist masters of gloom even if, under a proper rule of law, a society must let them speak.

Indeed, as Albert Dicey set out in 1914 in the famous eighth edition of his seminal treatise on constitutional law, the grip of the rule of law can slip for the same reason that it can be strengthened, namely because the attitude of the citizenry may involve a loss of faith:

Till a time well within the memory of persons now living, it would have been very difficult to find any body of men or women who did not admit that, broadly speaking, a breach of the law of the land was also an act of immorality. No doubt at all times there have existed, as at the present day, a large number of habitual

74 Grégoire CN Webber, The Negotiable Constitution: On the Limitation of Rights (Cambridge: Cambridge University Press, 2009) at 1-12, 160-73.

75 See the discussion at the conclusion of Part VII, below, of how the framers of the American Constitution had wide differences of opinion about what the document they executed actually meant.

76 Schuette v Coalition to Defend Affirmative Action, 134 S Ct 1623 (2014). 
law-breakers, but though a cheat, a pickpocket, or a burglar does constantly break the law, there is no reason to surmise that cheats, pickpockets, or burglars maintain the doctrine that law-breaking is itself a praiseworthy or a moral act. ${ }^{77}$

And in the same work, Dicey promptly added:

Within the last thirty years, however, there has grown up in England, and indeed in many other civilised countries, a new doctrine as to lawlessness. This novel phenomenon, which perplexes moralists and statesmen, is that large classes of otherwise respectable persons now hold the belief and act on the conviction that it is not only allowable, but even highly praiseworthy, to break the law of the land if the law-breaker is pursuing some end which to him or to her seems to be just and desirable. This view is not confined to any one class. ${ }^{78}$

In other words, even a century ago, a threat to the rule of law could be seen to develop when there comes to be a growing disconnect between the general consensus of what the law should be and what the law does in actuality. In a democracy this should not be an insoluble problem because, as Abraham Lincoln famously said, "[t]he best way to get a bad law repealed is to enforce it strictly."79 Dicey went on to add this to the above:

Democratic sentiment, further, if not democratic principle, demands that law should on the whole correspond with public opinion; but when a large body of citizens not only are opposed to some law but question the moral right of the state to impose or maintain a given law, our honest democrat feels deeply perplexed how to act. He does not know in effect how to deal with lawlessness which is based upon a fundamental difference of public opinion. ${ }^{80}$

An essential element of the rule of law, therefore, is the need to ensure that the content of promulgated laws continues to persuade and to encourage trust, thus dispelling the querulous and self-serving views that continuously arise and which, either deliberately or recklessly, undermine the common good. Society is bolstered not only by how the promulgated laws are expressed, but by the ongoing fairness, regularity, predictability, and service of social justice that the rule of law conceptually demands of, and enforces on, all branches of government (including the judicial branch) in apparent operational reality of those promulgated laws.

As a result of this, the complication that Dicey predicted arises in the need to keep the promulgated laws consistent with the better nature of the citizenry. Dicey's complication arises where people challenge the sufficiency or validity of the rule of law itself by reason

Albert Venn Dicey, Introduction to the Study of the Law of the Constitution, 8th ed (London: Macmillan, 1915) at xli [Dicey, 8th ed]. Dicey is said to have coined the phrase "rule of law." See Bingham, supra note 56.

Ibid.

79 See e.g. JRW Morris Jr, “Ignorance of the Law Excuses No One” (1915) 8:5 Lawyer \& Banker 319 at 324. Abraham Lincoln was the sixteenth President of the United States, serving from March 1861 until his assassination in April 1865: James M McPherson, "Lincoln, Abraham” in American National Biography Online (Oxford: Oxford University Press, 2000). In his inaugural address on 4 March 1861, he said "Why should there not be a patient confidence in the ultimate justice of the people? Is there any better or equal hope in the world?” See Edward McPherson, The Political History of the United States of America During the Great Rebellion (Washington: Philp \& Solomons, 1864) at 108. 
of disbelief in the sufficiency or validity of the content of the promulgated laws in a given society. As society matures and becomes more civilized, so should the promulgated laws, and the rule of law itself becomes even more grand and noble.

In 2006, Anthony Kennedy, a distinguished judge of the Supreme Court of the United States in a speech to the American Bar Association said that: "[I]f the rule of law is to have meaning, substance, hope, inspiration for the rest of the world, it must be coupled with the opportunity to improve human existence." ${ }^{\text {"1 }}$ He referred to the anomaly of a jurist seeking to explain to a homeless person sleeping on a grate that he has the right to trial by jury. In this regard, Justice Kennedy offered an example of an insufficient rule of law even if expected features were present.

From comments of Lord Bingham and Justice Kennedy, it is arguable that maintaining, as well as invigorating, the rule of law often depends not merely on the internal controls or clemency within it, but on its encouragement of generosity, progress, and humanity. Justice Kennedy added, referring to the famous work of Solzhenitsyn:

\footnotetext{
We just define law differently than [Solzhenitsyn] did. From his era, from his culture, law was a diktat, a ukase, a command, a mandate; in sum, it was a cold decree. That's not the meaning of law as our nation and our co-democracies define it. For us law is a liberating force. It's a promise; it's a covenant; it says that you can hope, you can dream, you can dare. You can plan; you have joy in your existence. That's the meaning of the law as Americans understand it and that's the meaning of the law as we must explain it to a doubting world where the verdict is still out. ${ }^{82}$
}

With that in mind, Justice Kennedy offered a three part definition of the rule of law that might be compared with the three part definition proposed by Dicey in the tenth edition of his work. ${ }^{83}$ Dicey had suggested this:

It means, in the first place, the absolute supremacy or predominance of regular law as opposed to the influence of arbitrary power, and excludes the existence of arbitrariness, of prerogative, or even of wide discretionary authority on the part of government.

It means, again, equality before the law, or the equal subjection of all classes to the ordinary law of the land administered by the ordinary law courts... [without] any exemptions of officials or others from the duty of obedience to the law.

“Justice Kennedy Address”(5 August 2006), online: C-Span < www.c-span.org/video/?193757-1/justicekennedy-address >. Full text available at "Justice Kennedy at the ABA" (15 August 2006), online: Hannah Blog <hannah.smith-family.com/?p=1549> [“Kennedy”].

82 Ibid; see e.g. Alexander Solzhenitsyn, One Day in the Life of Ivan Denisovich, translated by Ralph Parker (New York: Penguin Books, 1963). 
The "rule of law," lastly, may be used as a formula for expressing the fact that with us the law of the constitutional ... are not the source but the consequence of the rights of individuals ... thus the constitution is the result of the ordinary law of the land. ${ }^{84}$

By comparison in his 2006 speech to the American Bar Association, Kennedy proposed this three part provisional view:

The Law is superior to, and thus binds, the government and all its officials.

The Law must respect and preserve the dignity, equality, and human rights of all persons. To these ends the Law must establish and safeguard the constitutional structures necessary to build a free society in which all citizens have a meaningful voice in shaping and enacting the rules that govern them.

The Law must devise and maintain systems to advise all persons of their rights, and it must empower them to fulfill just expectations and seek redress of grievances without fear of penalty or retaliation. ${ }^{85}$

Compared to both of these (and compared to what this article later proposes to be a number of applications of the rule of law) there is an outstanding capsule formulation of the rule of law given by a former Secretary General of the United Nations in 2004:

It refers to a principle of governance in which all persons, institutions and entities, public and private, including the State itself, are accountable to laws that are publicly promulgated, equally enforced and independently adjudicated, and which are consistent with international human rights norms and standards. ${ }^{86}$

In the end, the relationship between the rule of law and "good" law is that the former provides the means and environment for "good" law to come into being and to work on an ongoing basis. In response, the "good” law invigorates and expands the matrix of values contained within the rule of law.

Before attempting to survey aspects of the rule of law as it now appears to exist in Canada, it is useful to consider the emergence of the rule of law in our history as it came to be received by Canada, and also to consider some of the formal expressions of the rule of law as they appear in the Canadian Constitution.

\section{RULE OF LAW AS INHERITED BY CANADA}

The concept of an overarching rule of law as compared to the hit and miss rule of specific persons, coupled with the concept that society and its people are fundamentally governed by law and thus not subject to arbitrariness or inequity has, as noted above, largely gathered strength and detail over the centuries, emanating from emerging English (and to an extent

As summarized by Rich Cassidy, "The Rule of Law: Supreme Court Justice Anthony Kennedy Tells us What it means and why it Counts” (4 May 2010), online: On Lawyering < onlawyering.com/2010/05/ the-rule-of-law-supreme-court-justice-anthony-kennedy-tells-us-what-it-means-and-why-it-counts/> . Report of the Secretary-General, UN Doc S/2004/616) (23 August 2004) at para 6, online: <www. unrol.org/files/2004\%20report.pdf>. 
European) norms and philosophy of free democracy. ${ }^{87}$ As Dicey wrote, one of the chief features that had characterized the development of the political institutions of England since the Norman Conquest was the supremacy of law. ${ }^{88}$ It was that supremacy, connected with the unique legitimacy conferred by the people being represented by persons of their choice in the production of legislated law, which was the greatest achievement for society since "1066 and all that." 89

In the histories of English democracy, courts initially came into existence to resolve disputes and to administer the rules of the monarch and, more practically, to raise revenue. In early Norman England, justice was administered in local courts, or by sheriffs in the meantime. The laws were parochial and yet still had strong elements of conventionalism. But as the power of the King increased, the Royal Courts became both prominent and dominant, not to mention visible. Indeed, the word "court" itself was a carry over from the royal meeting area. In those early days, the court was nonetheless a location of undivided power dealing with what we would now consider legislative, executive, and judicial functions.

While the power originally followed the King's person in his progress around the country, various legal fictions appeared to maintain the royal authority even in his absence. The Courts of King's Bench, Exchequer, and Common Pleas had already a Chief Justice each and an entity by the fourteenth century, but they were still servants of the Crown. On the other hand, they were on their own, and the attitude emerged that they were not really emanates of the King but the Crown, with the Crown symbolically representing the people and the laws of England.

Dismissals of Chief Justice Sir John Markham in 1469 by Edward IV and Chief Justice Sir Edward Coke by James I for disobedience of royal directions exemplified the effort to "correct” this attitude change of the King's Bench judges. ${ }^{90}$ But like Canute, ${ }^{91}$ the monarchs

87 Bingham notes several "milestones" in the development of the rule of law that this section of the article will examine in more depth, namely: (1) the Magna Carta, (2) habeas corpus, (3) the Petition of Right, 1628, (4) Mathew Hale's resolutions, (5) the Habeas Corpus Amendment Act, 1679, and (6) the Bill of Rights, 1689 and the Act of Settlement, 1701 (Bingham, supra note 56 at 10-25).

$88 \quad$ Dicey, 10th ed supra note 83 at 183.

89 Walter Carruthers Sellar \& Robert Julian Yeatman, 1066 and All That: A Memorable History of England (New York: EP Dutton, 1931) was a humorous reworking of the history of England, stylistically written as if it were to teach younger children about their nation's history but including mixed-up facts and sardonic observations. The book is a parody of history teaching in English schools of the era. It concludes, at 115, with the end of World War I, at which time "America was thus clearly top nation, and history came to a .” The ".” refers to the English concept of the "full stop” and not the American usage of "period.” Amusingly, some benefits of the rule of law are implied even in this comical viewpoint. John Campbell, The Lives of the Chief Justices of England, vol 1 (London: John Murray, 1849) at 14344, 292-94. As Chief Justice, Sir Edward Coke in Dr. Bonham's Case, declared the King to be subject to the law, and the laws of Parliament to be void if in violation of "common right and reason" ( $\mathrm{Dr}$ Bonham's Case (1610), 8 Co Rep 114a at 118a, 77 ER 646 (KB)). He was initially moved to the Chief Justiceship of the King's Bench but he continued to affront royal power leading to his dismissal from the bench on 14 November 1616. But he lived on to Parliamentary office and to complete his famous Institutes before his death in 1634. See Allen D Boyer, “Coke, Sir Edward (1552-1634)” in Mathew \& Harrison, supra note 69.

91 Canute was an old king of England is said to have commanded the tide to cease rising in order to demonstrate the futility of a king's law compared to God's law. See Henry of Huntingdon, The Chronicles, translated by Thomas Forester (London: Henry G Bohn, 1853) at 199. 
could not turn back the tide towards the rule of law and its primary method of application: an independent and impartial judiciary. Indeed, the kings themselves must have sensed the rule of law as being something within the very nature of being a citizen of England. ${ }^{92}$

The judges of the royal courts of the eras evidently were imbued to some greater or lesser degree with that sentiment of some great notion of law (whether they thought of it as the rule of law or not) which was part of the very chairs they sat on. Even Chancery, which emerged from the role of the King in Council, began to break loose. Powerful monarchs attempted to create more amenable tribunals, such as the Court of the Star Chambers, but most of these were gone by $1641 .^{93}$

Two storied resources dramatically bespeak the venerable history of the rise of the rule of law, antecedent to our Canadian story. Blackstone saw in the Magna Carta a wellspring of the rule of law, writing this about it:

A third subordinate right of every Englishman is that of applying to the courts of justice for redress of injuries. Since the law is in England the supreme arbiter of every man's life, liberty, and property, courts of justice must at all times be open to the subject, and the law be duly administered therein. The emphatic words of magna carta, spoken in the person of the king, who in judgment of law (says sir Edward Coke), is ever present and repeating them in all his courts, are these; "nulli vendemus, nulli negabimus, aut differemus rectum vel justitiam" [to none will we sell, to none deny, to none delay either right or justice]: and therefore every subject," continues the same learned author, "for injury done to him in bonis, in terris, vel persona [either in his goods, lands, or person], by any other subject, be he ecclesiastical or temporal, without any exception, may take his remedy by the course of the law, and have justice and right for the injury done to him, freely without sale, fully without any denial, and speedily without delay."94

Blackstone knew whereof he spoke. Even before the respected Coke (who nonetheless himself demonstrated some of the weaknesses of human nature in his career) there was an example in the reign of Henry V as described by Sir Robert Megarry drawing from an earlier source:

The most renomed prince, kynge Henry the fifte, late kynge of Englande, durynge the life of his father was noted to be fierce and of wanton courage. It hapned that one of his seruantes whom he well fauored, for felony by hym committed, was arrayned at the kynges benche; whereof he being aduertised, and incensed by light persones about hym, in furious rage came hastily to the barre, where his seruant stode as a prisoner, and commaunded hym to be unygued and sette at libertie, where at all men were abasshed, reserued the chiefe iustice, who humbly exhorted the prince to be contented that his seruant moght be ordred accordyng to the auncient lawes of this realme, or if he wolde haue hym saued from the rigour of the lawes, that he shuld optaine, if he moughte, of the kynge, his father, his gracious pardone; whereby no lawe or iustice shulde be derogate. With whiche answere the prince nothynge appeased, but rather more inflamed, endeuored

Arguably, Alfred the Great had such a sentiment for his people well prior to 1066 with his devotion to both formal law and education to understand it. For more discussion on Alfred the Great, see infra note 100 .

94 Blackstone, supra note 51, vol 1 at 102 [footnotes omitted]. Latin translation provided by Jones, supra note 51 at 27. 
hym selfe to take away his seruant. The iuge consideringe the perilous example and inconuenience that moughte thereby ensue, with a valiant spirite and courage commaunded the prince upon his alegeance to leue the prisoner and departe his waye. With whiche commandment the prince, being set all in a fury, all chafed, and in a terrible manner, came up to the place of iudgment - men thinkyng that he wolde have slayne the iuge, or haue done to hym some damage; but the iuge sittyng styll, without movynge, declaynge the maiestie of the kynges place of iudgment, and with an assured and bolde countenance, hadde to the prince these words folowyng: Sir, remember your selfe; I kepe here the place of the king, your soueraigne lorde and father, to whom ye owe double obedience, wherfore, eftsones in his name, I charge you desiste of your wilfulnes and unlaufull entreprise, and from hensforth gyue good example to those whiche hereafter shall be your propre subiectes. And nowe for your contempt and disobedience, go you to the prisone of the kynges benche, where unto I committe you; and remayne ye there prisoner untill the pleasure of the kynge, your father, be further knowen. With whiche wordes beinge abasshed, and also wondrynge at the meruailous grauitie of that worshipful Justice, the noble prince, layinge his waipon aparte, doinge reuerence, departed and went to the kynges benche as he was commaunded. Whereat his seruants disdainyng, came and shewed to the kynge all the hole affaire. Wherat he a whiles studienge, after as a man all rauisshed with gladness, holdyng his eien and handes up towardes heuen, abrayded, sayinge with a loude voice, O mercifull god, howe moche am I, aboue all other men, bounde to your infinite goodnes; specially for that ye haue gyuen me a iuge, who feareth not to ministre iustice, and also a sonne who can suffre semblably and obey iustice? ${ }^{95}$

The reference by Blackstone to the Magna Carta might be characterized in part as a clear demonstration of how the rule of law gained its strength by people "talking it up" or, in a sense, marketing it as a good idea. At the beginning of this article it was asserted the rule of law is a concept of the mind and an honour system. The way in which Blackstone discusses and explains the Magna Carta shows why. Blackstone was not merely stating what he believed to be the foundations of the law: he was advocating for them. Blackstone was not a mere reporter of a gathered jurisprudence, but a teacher and sponsor of the greatness of the rule of law. Blackstone's assertion of a golden place in English history for the Magna Carta and his similar encomium elsewhere for what he called the "great and efficacious writ ... of habeas corpus" 96 was not just a brilliant exposition of how the filaments of history had produced the rule of law and an independent judiciary to enforce it, but it was a passionate endorsement of the concept and honour of the rule of law.

This can be further appreciated by noting that despite the way Blackstone characterized it as a legal monument, the Magna Carta was in actuality not a statute or constitution as any of us would presently understand it. It was more like an undertaking of the Crown. The Magna Carta was not a sudden thing, nor was it merely a peace treaty that settled a temporary dispute between King John (known disparagingly as Lackland) ${ }^{97}$ and a gaggle of

Sir Robert Megarry, A Second Miscellany-at-Law: A Further Diversion for Lawyers and Others (London: Stevens \& Sons, 1973) at 77-78, quoting Sir Thomas Elyot, The Boke Named the Gouernour (London: Thomas East, 1580) at 101-102. See also Raphaell Holinshed, Holinshed's Chronicles England, Scotland, and Ireland, vol III (New York: Ams Press, 1965) at 61. Raphaell Holinshed, with several others, produced a history from work commenced by Reginald Wolfe in 1548 and still unfinished in 1573 when Wolfe died. It is said that William Shakespeare used the revised second edition of the Chronicles (published in 1587) as the source for 13 of his plays. See e.g. Elizabeth Story Donno, "Some Aspects of Shakespeare's Holinshed” (1987) 50:3 Huntington Library Q 229 at 229.

97 Frank McLynn, Lionheart and Lackland: King Richard, King John and the Wars of Conquest (London: Vintage, 2007) at 36. 
Barons, hardly social liberals in their own right. A key point is that the Barons felt justified in their conduct not merely because John had given the "smack of firm government" country, or because he bungled some military excursions, but because there already was a tradition of established law abroad in the land. Despite his disputes with the church, the Pope some months later helped John attempt to renege on the Magna Carta. ${ }^{99}$ But with alongside that great undertaking, something marvelous had been already happening in the psyche of the people of England, even though, most of them being illiterate, had little clear understanding about it.

Such an averment by a King as in the Magna Carta was not unprecedented, since most Kings since Alfred the Great showed some genuine commitment to their people. ${ }^{100}$ With Henry I's Charter of Liberties in 1100 and some of the exactions of his predecessor such as overly harsh punishments, ${ }^{101}$ and with Henry II's Assize of Clarendon in 1166, ${ }^{102}$ a fairly reliable customary view had arisen regarding royal promises to ensure the royal writ would run and that justice would be given to every freeman throughout the country. In that light, James Holt asserts that: "Magna Carta was not a sudden intrusion into English society and politics. On the contrary, it grew out of them.... Laymen had been assuming, discussing and applying the principles of Magna Carta long before 1215. They could grasp it well enough." 103

In other words, before the Magna Carta, it had already come to be accepted, at least at the philosophical level, that unbridled and unaccountable royal power should not be the law of England. So it was not so much what it specifically said, but what it implied, and, hence, what it meant, that made the Magna Carta great. Even the name bespoke greatness.

The link between what the Magna Carta asserted about royal rule, on the one hand, and what English people had come to believe as intrinsic to royal rule on the other, made precision in the later historical reporting of the Magna Carta relatively unimportant in the

See Ruth Dudley Edwards, The Pursuit of Reason: The Economist, 1843-1993 (London: Hamish Hamilton, 1993) at 786.

JC Holt, Magna Carta, 2nd ed (Cambridge: Cambridge University Press, 1992) at 261, 374-75.

Alfred King of Wessex from 871 to 899 and styled King of the Anglo Saxons was a monarch who believed in education for his people, the spread of literacy particularly in the English language and the encouragement of school for his court. He personally contributed to translation of great works that he deemed "most necessary for all men to know." He also developed a long domboc or law code, consisting of his "own" laws followed by a code issued by his late seventh-century predecessor King Ine of Wessex. The laws, arranged into 120 chapters are introduced by him with personal notes that he gathered together the laws he found in many "synod-books" and "ordered to be written many of the ones that our forefathers observed — those that pleased me; and many of the ones that did not please me, I rejected with the advice of my councillors, and commanded them to be observed in a different way." Simon Keynes \& Michael Lapidge, Alfred the Great: Asser's Life of King Alfred and other contemporary sources (London: Penguin Books, 1983) at 28-29, 164. See also Patrick Wormald, "Alfred (848/9-899)" in Mathew \& Harrison, supra note 69.

Sir Frederick Pollock \& Frederic William Maitland, The History of English Law, 2nd ed (Cambridge: Cambridge University Press, 1898) vol 1 at 95.

“Assize of Clarendon,” Encyclopaedia Britannica (2015), online: <www.britannica.com/EBchecked/ topic/119804/Assize-of-Clarendon>: "a series of ordinances initiated by King Henry II of England in a convocation of lords at the royal hunting lodge of Clarendon. In an attempt to improve procedures in criminal law, it established the grand, or presenting, jury."

Holt, supra note 99 at 295. 
spread of its ideals. It was the belief in what the Magna Carta stood for that mattered most. The invocation of the Magna Carta as representative of the law of the land by the great minds of the day also helped to make it stick.

It was with that powerful sentiment in the common mind, and particularly, in the judicial mind, that what Blackstone called the "great writ" began to acquire both its symbolic and its actual authority to regulate exercises of political power. Habeas corpus had long been something of a tool along with certiorari and other prerogative authorities that had developed in the courts to facilitate their process of adjudication and review of petty tribunals, like sewer commissions or the miscellaneous miscreants hauled in by local justices, particularly face-to-face. ${ }^{104}$ But its rising as the key tool to challenge lawless executive action was the sea change in the consensus view of the rule of law. This was because, after all, the power to issue habeas corpus was possessed by the high judiciary, namely the King's Bench, and the writ was accessible by individuals who went to that court to seek it.

The Petition of Right, 1628, another turning point, followed upon a case where the remedy of habeas corpus was sought to bar summary demands of the King against five propertied knights. ${ }^{105}$ The King's Bench denial of bail in the case meant that habeas corpus had not been effective to prevent the five knights from being imprisoned to extract money from them to support plans of Charles I. But the silver lining of this set back for habeas corpus was that the Commons was driven to take steps to directly curb the power of the King. Ultimately, the defeat of the King's assertions of the right to expropriate property "per speciale mandatum domini regis" 106 from the five knights occurred when the Commons asserted their authority. In effect, they defined their enactments as the real authority of law as against the King's caprice.

In the Commons, the speakers for Parliamentary power invoked the Magna Carta while those who spoke for the King invoked monarchical traditions. In the end, the reluctant House of Lords and the even more reluctant King Charles I were forced to yield. Like John before him, Charles later attempted to pull back his assent to the Petition which, unlike the Magna Carta, was actually pushed through both the Commons and the reticent Lords to the King's signature to become a statute. Charles' attempts to stand athwart history in the next eleven years after that ultimately had fatal consequences. A military coup d'état ultimately followed with a form of Parliamentary government under Cromwell. ${ }^{107}$ But the real force of the rule of law persevered even through the interregnum.

Over the generations, habeas corpus expanded its value along with certiorari as the means of control of local courts (as their original forms were intended to do). In Bushell's Case, Edward Bushell was imprisoned for alleged misconduct as a juror, in that he failed to vote

Edith G Henderson, Foundations of English Administrative Law: Certiorari and Mandamus in the Seventeenth Century (Cambridge: Cambridge University Press, 1963) at 94, 102-104.

For a detailed look at the events surrounding the Petition of Right, see LJ Reeves, "The Legal Status of the Petition of Right” (1986) 29:2 Historical J 257.

"[B]y special command of his majesty": Elisabeth Zoller, Introduction to Public Law: A Comparative Study (Leiden: Martinus Nijhoff, 2008) at 93-94.

Pauline Gregg, King Charles I (London: Dent, 1981) at 428-33. 


\section{to convict William Penn and William Mead, said to be troublesome Puritans. Chief Justice Vaughan confidently wrote:}

The writ of habeas corpus is now the most usual remedy by which a man is restored again to his liberty, if he have been against law deprived of it.

Therefore the writ commands the day, and the cause of the caption and detaining of the prisoner to be certified upon the retorn, which if not done, the Court cannot possibly judge whether the cause of the commitment and detainer be according to law, or against it.

Therefore the cause of the imprisonment ought, by the retorn, to appear as specifically and certainly to the Judges of the retorn, as it did appear to the Court or person authorized to commit; else the retorn is insufficient, and the consequence must be,

That either the prisoner, because the cause retorn'd of his imprisonment is too general, must be discharg'd; when as if the cause had been more particularly retorn'd, he ought to have been remanded; or else he must be remanded, when if the cause had been particularly retorn'd, he ought to have been discharg'd: both which are inconveniences not agreeing with the dignity of the law. ${ }^{108}$

One of the many values Chief Justice Vaughan's decision in supporting the rule of law is that it also asserted - matter of factly — the proposition that any holders and executors of power, including local tribunals and magistrates, must do so under law, and must explain themselves. A passage perhaps less noticed in Bushell's Case, but of great implications for the later law of judicial review, is this:

The Court hath no knowledge by this retorn, whether the evidence given were full and manifest, or doubtful, lame, and dark, or indeed evidence at all material to the issue, because it is not retorn'd what evidence in particular, and as it was deliver'd, was given. For it is not possible to judge of that rightly, which is not expos'd to a mans judgment. But here the evidence given to the jury is not exposed at all to this Court, but the judgment of the Court of Sessions upon that evidence is only expos'd to us; who tell us it was full and manifest. But our judgment ought to be grounded upon our own inferences and understandings, and not upon theirs.

It was said by a learned judge, if the jury might be fined for finding against manifest evidence, the retorn was good, though it did not express what the evidence particularly was, whereby the Court might judge of it, because retorning all the evidence would be too long. A strange reason: for if the law allow me remedy for wrong imprisonment, and that must be by judging whether the cause of it were good, or not, to say the cause is too long to be made known, is to say the law gives a remedy which it will not let me have, or I must be wrongfully imprison'd still, because it is too long to know that I ought to be freed? What is necessary to an end, the law allows is never too long. Non sum longa quibus nihil est quod demere possis, is as true as any axiom in Euclid. Besides, one manifest evidence retorn'd had suffic'd, without retorning all the evidence. But the other Judges were not of his mind. ${ }^{109}$ 
All in all, the King's Bench in England found itself increasingly the source of the final opinion of what the law of the land was. Due credit for this must be given to the great early judges such as Coke, Holt, ${ }^{110}$ Hale, ${ }^{111}$ and Mansfield, ${ }^{112}$ as well as some of those whose pens were not limited to writings in judicial office, such as Bacon ${ }^{113}$ and Blackstone.

For his part, Hale presided over a Commission during the period of Cromwell, and produced recommendations such as reducing the use of the death penalty, allowing defendants access to legal counsel, legal aid, and the abolition of peine forte et dure as a torture mechanism. ${ }^{114}$ Almost all of the recommendations proposed by Hale eventually became part of English law. Hale was made a judge of the Common Pleas by Cromwell, but he insisted on the condition that he "would not be required to acknowledge the usurper's authority." 115 He also refused to try offenders against the state on the grounds that the government authorizing him to do so was illegal. ${ }^{116} \mathrm{He}$ also dismissed a jury that Cromwell had chosen for a case.

Sir John Holt, who served as Lord Chief Justice of England from 17 April 1689 until his death (see Paul D Halliday, "Holt, Sir John (1642-1710)" in Mathew \& Harrison, supra note 69). While much of his work built up the rules of contract and commerce, Holt also was famous for Ashby $v$ White (1703), 2 Raym Ld 938, 92 ER 126 (KB), a foundational case in English constitutional and tort law concerning the right to vote, as to holding a public officer accountable for misfeasance in office, and finally that $u b i$ jus, ibi remedium. He said at 953, "A right that a man has to give his vote at the election of a person to represent him in Parliament, there to concur to the making of laws, which are to bind his liberty and property, is a most transcendant thing, and of an high nature." He also wrote ibid, "If the plaintiff has a right, he must of necessity have a means to vindicate and maintain it, and a remedy if he is injured in the exercise or enjoyment of it, and, indeed it is a vain thing to imagine a right without a remedy; for want of right and want of remedy are reciprocal" [footnotes omitted]. Finally, at 956, he added, "To allow this action will make publick officers more careful to observe the constitution of cities and boroughs, and not to be so partial as they commonly are in all elections, which is indeed a great and growing mischief, and tends to the prejudice of the peace of the nation."

Sir Matthew Hale is noted for his treatise Historia placitorum coronce, or Pleas of the Crown being the first published history of English law. This had a strong influence on Blackstone's Commentaries on the Laws of England and struck a middle-ground between Coke's "appeal to reason" and John Selden's "appeal to contract," while refuting elements of Hobbes's theory of natural law as quoted above. See Alan Cromartie, "Hale, Sir Mathew (1609-1676)" in Mathew \& Harrison, ibid.

The first Earl of Mansfield, William Murray's ascension to Lord Chief Justice of England followed a career in politics. Although briefly he had to hold the job as Chancellor of the Exchequer, his career as Lord Chief Justice was historic for its establishment of much of the law of commerce and property including copyright. James Oldham, "Murray, William, first earl of Mansfield (1705-1793)" in Mathews \& Harrison, ibid.

113 Sir Francis Bacon was an English philosopher, statesman, scientist, jurist, orator, essayist, and author. He served both as Attorney General and Lord Chancellor of England. He was a controversial figure, condemned in some quarters (and suspected of personal oddities), and he died as a result of scientific research. But he is regarded as a parent of the scientific method, applied both to actual science and law (the latter as to case precedent analysis). See Markku Peltonen, "Bacon, Francis, Viscount St Alban (1561-1626)" in Mathew \& Harrison, ibid; Julian Martin, Francis Bacon, the State and the Reform of Natural Philosophy (Cambridge: Cambridge University Press, 1992). John Hostettler, The Red Gown: The Life and Works of Sir Mathew Hale (Chichester: Barry Rose, 2002) at 41-50. The controversial Bacon had been more tolerant of this method for gaining information. See Elizabeth Hanson, “Torture and Truth in Renaissance England” (1991) 34 Representations 53 at 55. Edward Foss, Biographical Juridica: A Biographical Dictionary of the Judges of England (Boston: Little Brown, 1870) at 320. 
Remarkably, Cromwell seems to have been quite tolerant of Hale (and Selden), Hale being one of only two judges in the 400 member first Protectorate Parliament in $1654 .{ }^{117}$ Hale advocated that the government should be "in a Parliament and a single person limited and restrained as the Parliament should think fit." ${ }^{\text {"118 }}$ Cromwell refused to allow any members of Parliament into the Commons until they signed an oath recognizing his authority, which Hale refused to do so Hale's proposal was not enacted. But Cromwell still put Hale into what Cromwell accepted as a substitute for the House of Lords. ${ }^{119}$

Following the death of Cromwell and the departure of his ineffectual son, Richard Cromwell, Hale led negotiations for the return of the monarchy. ${ }^{120}$ Eventually Hale became Chief Justice of the King's Bench, where he was lauded for a calm and professorial demeanour, and his enthusiasm for teaching law as much as delivering it. ${ }^{121}$ Overall, Hale agreed with Selden that law was created through agreement, and disagreed that reason had an inherent binding power by itself.

Mansfield was loyal to the Crown and was not always favourable to freedom of expression when made against the Crown (thus attracting the suggestion he was a factor in the American Revolution). ${ }^{122}$ But Joseph Story, a judge of the Supreme Court of the United States, had a considerably more favourable view of Mansfield, as did many others. ${ }^{123}$ Mansfield's comments included these in the habeas corpus case of Somersett:

The state of slavery is of such a nature that it is incapable of being introduced on any reasons, moral or political; but only by positive law [statute], which preserves its force long after the reasons, occasions, and time itself from whence it was created, is erased from memory: it's so odious, that nothing can be suffered to support it, but positive law. Whatever inconveniences, therefore, may follow from the decision, I cannot say this case is allowed or approved by the law of England; and therefore the black must be discharged. ${ }^{124}$

$117 \quad$ Hostettler, supra note 114 at 63-64.

$118 \quad$ Ibid at 65.

$119 \quad$ Ibid at 69.

$120 \quad$ Ibid at 69-74.

$121 \quad$ Ibid at 134.

122 At least, so argued John Quincy Adams in 1829. See Julian S Waterman, “Mansfield and Blackstone’s Commentaries” (1934) 1:4 U Chicago L Rev 549 at 552.

123 Joseph Story, said that Mansfield “'broke down the narrow barrier of the common law' and redeemed it from 'feudal selfishness and barbarity' [and] that 'he was one of those great men raised up by Providence, at a fortunate moment, to effect a salutary revolution in the world'”: ibid at 549. Oliver Wendell Holmes Jr, another judge, approved of Mansfield's emphasis on results instead of merely following principles (see Frederic R Kellogg, Oliver Wendell Holmes, Jr., Legal Theory, and Judicial Restraint (Cambridge: Cambridge University Press, 2007) at 67, discussing Holmes' reference to Mansfield in his article "Codes, and the Arrangement of the Law" (1870) 5:1 Am L Rev 1 at 1). Mansfield had written, "the law of England would be a strange science indeed if it were decided upon precedents only. Precedents serve to illustrate principles, and to give them a fixed certainty" in Jones $v$ Randall, (1774) 1 Cowp 37 at 39, 98 ER 954 (KB) and "as the usages of society alter, the law must adapt itself to the various situations of mankind” in Barwell v Brooks, (1784) 3 Doug 371 at 373, 99 ER $702(\mathrm{~KB})$.

$124 \quad$ Somerset $v$ Stewart (1772), Lofft 1 at 19, 98 ER 499 (KB). This holding was an adoption of an earlier position expressed by Holt in Smith $v$ Brown, (1702) 2 Salk 666, 91 ER 566 (KB). 


\section{More potently still, Mansfield in $R v$ Wilkes said:}

It is fit to take some notice of the various terrors hung out; the numerous crowds which have attended and now attend in and about the hall [Westminster Hall, the home of the law courts], out of all reach of hearing what passes in Court; and the tumults which in other places, have shamefully insulted all order and government [i.e. riots]. Audacious addresses in print dictate to us, from those they call the people, the judgment to be given now, and afterwards upon the conviction. Reasons of policy are urged, from danger to the kingdom, by commotions and general confusion.

Give me leave to take the opportunity of this great and respectable audience, to let the whole world know, all such attempts are vain. Unless we have been able to find an error which will bear us out, to reverse the outlawry; it must be affirmed. The constitution does not allow reasons of State to influence our judgments: God forbid it should! We must not regard political consequences; how formidable soever they might be: if rebellion was the certain consequence, we are bound to say "fiat justitia, ruat coelum” [let right be done though the heavens fall].... We are to say what we take the law to be: if we do not speak our real opinions, we prevaricate with God and our own consciences.

I pass over many anonymous letters I have received. Those in print are public: and some of them have been brought judicially before the Court. Whoever the writers are, they take the wrong way. I will do my duty unawed. What am I to fear? The mendax infamia from the press, which daily coins false facts and false motives? The lives of calumny carry no terror to me. I trust, that my temper of mind, and the colour and conduct of my life, have given me a suit of armour against these arrows.... I honour the King; and respect the people: but many things acquired by the favour of either, are, in my account, objects not worth ambition. I wish popularity: but, it is that popularity ... which, sooner or later, never fails to do justice to the pursuit of noble ends, by noble means. I will not do that which my conscience tells me is wrong, upon this occasion, to gain the huzzas of thousands, or the daily praise of all the papers which come from the press: I will not avoid doing what I think is right; though it should draw on me the whole artillery of libels; all that falsehood and malice can invent, or the credulity of a deluded populace can swallow.

Once for all, let it be understood, "that no endeavours of this kind will influence any man who at present sits here.” If they had any effect, it would be contrary to their intent: ... But I hope, and I know, that I have fortitude enough to resist even that weakness. No libels, no threats, nothing that has happened, nothing that can happen, will weigh a feather against allowing the defendant, upon this and every other question, not only the whole advantage he is intitled to from substantial law and justice; but every benefit from the most critical nicety of form, which any other defendant could claim under the like objection. The only effect I feel, is an anxiety to be able to explain the grounds upon which we proceed; so as to satisfy all mankind "that a flaw of form given way to in this case, could not have been got over in any other."125

It has come to be accepted in the Canadian view of the rule of law that the core means of keeping the scope and manner right is that of unimpeded and equal access to open, independent, and impartial courts. But this was a comparatively radical idea back then, even 
if quietly taking hold. To do this effectively of course, the courts needed to be recognized as the separate and equal judicial branch of government, independent of the executive and legislative branch, but not dictating to them either. In the United States, Chief Justice Marshall later put it this way, grounding his opinion in the United States Constitution: "It is emphatically the province and duty of the judicial department to [s]ay what the law is."126

It was not always so. But progress towards our modern view of the crucial character of the independent and impartial judiciary is a demonstration of how wisdom of our maturing societies produced not merely strong individuals as judges, but the remarkable collaboration of everyone else in the emergence of that keystone of the rule of law.

This transformation of the courts of England from their function in resolving private suits and in their administration of special public laws, notably the criminal and penal laws, came alongside the development of the modern tripartite design of democracy. It was not just the suggestions of Locke, but the impractical steps of Cromwell in his 1653 Instrument of Government, that helped move the nation towards that design. ${ }^{127}$ Remarkably, as noted, Cromwell not only permitted the courts to continue, but he even advanced the position of Hale as a leading judge for his new order. Hale ultimately outlasted Cromwell as did the court system which Cromwell had inherited. So although Cromwell did not himself institute tripartite government (in some senses his generals had a rather impoverished view of democracy), ${ }^{128}$ his governance did not deflect the continued evolution of the rule of law in an environment of that sort.

The rule of law now asserts that the executive, legislative, and judicial branches of government are individually duty-bound to respect the reasonable expectations and entitlements of law. Part of this is that they are obliged to defer jurisdiction to each other. And part of this is that the courts assembled in the judicial branch exist to guarantee legality through effective powers of surveillance over the legitimacy, integrity, and fairness of all agencies of government and to provide for effective remedies in the instance of shortfall. Independence is therefore crucial.

Montesquieu wrote The Spirit of the Laws ${ }^{129}$ in 1748, building on the work of Locke, and using the English political evolution of the seventeenth and eighteenth centuries as his structural model. He wrote that the executive, legislative, and judicial functions of government should be assigned to different bodies so that attempts by one branch of government to infringe on political liberty might be restrained by the other branches. ${ }^{130}$

It should be recalled that Montesquieu did not have in mind the scope of judicial duty that is currently recognized in Western democracies (that is itself a clear indication of the

\footnotetext{
$126 \quad$ Marbury v Madison, 5 US (1 Cranch) 137 at 177 (1803).

$127 \quad$ Hostettler, supra note 114 at 62.

128 See Patrick Little, “Major-generals (act. 1655-1657)” in Lawrence Goldman, ed, Oxford Dictionary of National Biography, online ed (Oxford: Oxford University Press, 2014).

129 Montesquieu, The Spirit of the Laws, translated \& ed by Anne M Cohler, Basia Carolyn Miler \& Harold Samuel Stone (Cambridge: Cambridge University Press, 1989).

130 Ibid ("[n]or is there liberty if the power of judging is not separate from legislative power and from executive power" at 157).
} 
evolving nature of the rule of law). Nonetheless, in 1751 the Catholic Church added The Spirit of the Laws to its Index Librorum Prohibitorum ("List of Prohibited Books"), perhaps resenting the possibility that courts might take over the guiding role of the Church in fixing norms. $^{131}$

Montesquieu was able to reflect back on the coming into existence of several noteworthy enactments of the English Parliament which, like the Magna Carta, are foundational to the early terms that help define what it means to be a citizen under a rule of law. So did Blackstone, who likewise endorsed the view that: "Nothing therefore is more to be avoided, in a free constitution, than uniting the provinces of a judge and a minister of state.”132

One noteworthy post-Restoration enactment is the Habeas Corpus Amendment Act, $1679^{133}$ which followed the Restoration. Charles II was a disappointing revival of the monarchy. His chief minister, the Earl of Clarendon, fell quickly into a practice of removing prisoners to "remote islands, garrisons, and other places, thereby to prevent them from the benefit of the law," ${ }^{134}$ namely the reach of habeas corpus through England and Wales. The Commons saw through with five attempts to legislatively oust this abuse of power but failed by being blocked by the Lords. ${ }^{135}$ It is said that English political history was changed when Lord Grey, active in support of the bill, managed to hustle the opposing lords by counting a substantially fat Lord in favour as ten votes. ${ }^{136}$ Whether or not that is so, the Act got through in a close vote of 57 to 55 which even the famous historian Holdsworth suggested may have been a "miscount." 137 Clarendon was impeached and fled into exile. Howsoever dubious the provenance of this statute, it solidified the power of habeas corpus.

Another highly significant statute is the Bill of Rights, $1689,{ }^{138}$ passed on 16 December 1689. Interestingly, this bill was also something of a contract whereby both a King and Queen were invited to take over after the restoration of the Crown in England and the dismissal of James II. The Bill of Rights, 1689 was a restatement in statutory form of the Declaration of Right presented by the Convention Parliament to William and Mary in February 1689 inviting them to become the joint sovereigns of England. ${ }^{139}$ The Bill of Rights, 1689 stated that

No Monarch could again rely on divine authority to override the law. The authority and independence of Parliament was proclaimed; the integrity of its proceedings was protected and there could be no standing army in time of peace without its sanction. The power to suspend laws without the consent of Parliament was condemned as illegal. So was the power of dispensing with laws or the execution of laws.... Personal liberty

Hilary Bok, "Baron de Montesquieu, Charles-Louis de Secondat” in Edward N Zalta, ed, The Stanford Encyclopedia of Philosophy (2014), online: <plato.stanford.edu/entries/montesquieu>.

Blackstone, supra note 51, vol 1 at 201-202.

(UK), 31 Cha 2, c 2.

Bingham, supra note 56 at 22.

Ibid at 22-23.

Ibid.

Sir William Holdsworth, A History of English Law, vol 9, 3rd ed (London: Sweet \& Maxwell, 1944) at 117.

(UK), 1 Wm \& Mar 2, c 2.

Bingham, supra note 56 at 23-24. 
and security were protected by prohibiting the requirement of excessive fines, the imposition of excessive bail, and the infliction of "cruel and unusual punishments." 140

James' flight from England in the wake of the Glorious Revolution was also declared to be an abdication by him of the throne. ${ }^{141}$

Another of the enactments that was foundational for Canada was the Act of Settlement, $1701,{ }^{142}$ which, once again, was a somewhat practical statute intended to settle the succession to the crown and pass it to the Electress Sophia of Hanover and her Protestant heirs. ${ }^{143}$ Mary had died in 1694 and William did not remarry. The Bill of Rights, 1689 had validated Mary's sister Princess Anne to follow on the throne, but her own child died at age 11, and thus Parliament took steps to arrange that she be followed by the Electress.

Most of the Act of Settlement, 1701 was related to the continuity of non-Catholic government in the United Kingdom, but some features sought to protect the independence of legislators in Parliament from influence by the monarch. ${ }^{144}$ Another feature was that judges' commissions were valid quamdiu se bene gesserint (during good behaviour). If they did not behave themselves, they could be removed only by both Houses of Parliament. This provision was the result of various monarchs influencing judges' rulings, and its purpose was to assure judicial independence.

It would be possible to continue the colourful narrative of how the rule of law was built further in England, but with these enactments and with their profound impact upon Canada's express acceptance of them, it is appropriate to turn to Canada's situation. ${ }^{145}$ One last point before doing so, however, is to make one thing clear for historical accuracy. Virtually all of the major figures, including judges, mentioned so far, did not forecast an ability of judges to overrule legislation even if accepting the need for judicial independence. Rather, as Bingham said:

As Goldsworthy demonstrates, to my mind wholly convincingly, the principle of parliamentary sovereignty has been endorsed without reservation by the greatest authorities on our constitutional, legal and cultural

Ibid at 24 [footnotes omitted].

It should be noted, parenthetically, that the oft-made suggestion that the Glorious Revolution was local and comparatively brief in time is not faithful to the entire record. Steve Pincus, in 1688: The First Modern Revolution (New Haven: Yale University Press, 2009) at 5-10 contends that James II had in mind a modernization program that emphasized centralized control, repression of dissidents, and territorial empire. The revolutionaries, by contrast, saw new economic possibilities in a bureaucratic but participatory state resulting not only in a reconfigured English political order, but transformation of English foreign policy, religious culture, and political economy.

(UK), 12 \&13 Will 3, c 2.

Robert Stevens, "The Act of Settlement and the Questionable History of Judicial Independence” (2001) 1:2 OUCLJ 253 at 258-59.

Ibid at 259, 261.

JE Cote, writing prior to his appointment to the Alberta Court of Appeal, in "The Reception of English Law" (1977) 15:1 Alta L Rev 29 at 30, observed that reception of the English law "permitted the country's common law provinces to adopt a common law system without having to 'spend nine centuries painfully building up a system of judge-made law'” (quoted by the Supreme Court in Conseil scolaire francophone de la Colombie-Britannique v British Columbia, 2013 SCC 42, [2013] 2 SCR 774 at para $14)$. 
history. I need only mention Lord Burghley, Sir Robert Cecil, Sir Matthew Hale, Francis Bacon, John Selden, John Locke, the Marquess of Halifax, Blackstone, Adam Smith, Samuel Johnson, Lord Hardwicke, Montesquieu, Thomas Paine, Maitland, Holdsworth, Dicey. ${ }^{146}$

From this it would seem correct to deduce that the concept of legal supremacy expressed in the Constitution of Canada, whereby the courts have the role of declaring what the law of the Constitution "is" and therefore whether a promulgated law is consistent with it or not (or inoperable or not) is, in its own right, a product of the experience and policy of the United States. There is not a little irony in that event since, as will be seen in Part 2 of this article, ${ }^{147}$ even the framers of the United States Constitution did not all see eye-to-eye. The fact that they all differed about who should have primacy is probably the reason checks and balances emerged after the Constitutional Congress. In any event, the foregoing parade of sage ancestors from England and America together set the stage for what we have now. 